NBER WORKING PAPER SERIES

\title{
EXECUTIVE COMPENSATION AND CORPORATE GOVERNANCE IN THE U.S.: PERCEPTIONS, FACTS AND CHALLENGES
}

\author{
Steven N. Kaplan \\ Working Paper 18395 \\ http://www.nber.org/papers/w18395 \\ NATIONAL BUREAU OF ECONOMIC RESEARCH \\ 1050 Massachusetts Avenue \\ Cambridge, MA 02138 \\ September 2012
}

Kaplan serves on public company and mutual fund boards. Douglas Baird, Effi Benmelech, Carola Frydman, Austan Goolsbee, Jeff Miron, Lawrence Mishel, Raghu Rajan, Amir Sufi, Luke Taylor and Rob Vishny provided helpful comments. Wei Wu provided excellent research assistance. A version of this paper will appear in the Cato Papers on Public Policy. This paper also formed the basis for the 2012 Martin Feldstein Lecture at the NBER. I thank the Cato Institute, the Center for Research in Security Prices and the NBER for financial support. The views expressed herein are those of the author and do not necessarily reflect the views of the National Bureau of Economic Research.

NBER working papers are circulated for discussion and comment purposes. They have not been peerreviewed or been subject to the review by the NBER Board of Directors that accompanies official NBER publications.

(C) 2012 by Steven N. Kaplan. All rights reserved. Short sections of text, not to exceed two paragraphs, may be quoted without explicit permission provided that full credit, including $(\mathbb{C}$ notice, is given to the source. 
Executive Compensation and Corporate Governance in the U.S.: Perceptions, Facts and Challenges Steven N. Kaplan

NBER Working Paper No. 18395

September 2012, Revised September 2012

JEL No. G30,G32,J33,L2

\begin{abstract}
$\underline{\text { ABSTRACT }}$
In this paper, I consider the evidence for three common perceptions of U.S. public company CEO pay and corporate governance: (1) CEOs are overpaid and their pay keeps increasing; (2) CEOs are not paid for their performance; and (3) boards do not penalize CEOs for poor performance. While average CEO pay increased substantially through the 1990s, it has declined since then. CEO pay levels relative to other highly paid groups today are comparable to their average levels in the early 1990s although they remain above their long-term historical average. The ratio of large-company CEO pay to firm market value is roughly similar to its level in the late-1970s and lower than its pre-1960s levels. These patterns suggest that similar forces, likely technology and scale, have played a meaningful role in driving CEO pay and the pay of others with top incomes. With regard to performance, CEOs are paid for performance and penalized for poor performance. Finally, boards do monitor CEOs. The rate of CEO turnover has increased in the 2000s compared to the 1980s and 1990s, and is significantly tied to poor stock performance. While corporate governance failures and pay outliers as well as the very high average pay levels relative to the typical household undoubtedly have contributed to the common perceptions, a meaningful part of CEO pay appears to be market determined and boards do appear to monitor their CEOs. Consistent with that, top executive pay policies at over $98 \%$ of S\&P 500 and Russell 3000 companies received majority shareholder support in the Dodd-Frank mandated Say-On-Pay votes in 2011.
\end{abstract}

\author{
Steven N. Kaplan \\ Booth School of Business \\ The University of Chicago \\ 5807 South Woodlawn Avenue \\ Chicago, IL 60637 \\ and NBER \\ steven.kaplan@chicagobooth.edu
}




\section{Introduction}

Chief Executive Officers (CEOs) of public companies are routinely perceived to be overpaid and their boards are perceived to provide poor or limited oversight. These perceptions have three typical components: (1) CEOs are overpaid and their pay keeps increasing; (2) CEOs are not paid for performance; and (3) boards are not doing their jobs as monitors. For example, Bebchuk and Fried (2006) claim that, "flawed compensation arrangements have not been limited to a small number of "bad apples'; they have been widespread, persistent, and systemic."

In the last decade, the U.S. has implemented two major pieces of legislation designed to improve corporate governance. The scandals of Enron, WorldCom and others early in this century led to the Sarbanes-Oxley legislation in 2002. And the financial crisis led to the Dodd-Frank legislation in 2010 that includes a requirement that all public companies obtain an annual advisory shareholder vote on top executive pay ("say-on-pay"). Despite the legislation and attention, the perceptions and criticism continue. Recently, the New York Times wrote, "the top brass generally do much, much better than the rest of us, whether times are good or bad.", And Forbes wrote, "Our report on executive compensation will only fuel the outrage over corporate greed.",2

In this paper, I consider the accuracy of these perceptions today. What are the facts about CEO pay? Is it true that the typical CEO is not paid for performance? How much and how well do public company boards monitor their CEOs, particularly for poor performance? The recurring question I address is what are the drivers of CEO pay? Is pay driven by the power that CEOs wield over their boards leading CEOs to be overpaid? Is pay driven by a competitive market for talent (and CEOs are paid appropriately)? Or is pay driven by a combination of those and other forces?

What has happened to CEO pay over time? There are two ways to measure CEO pay. The first, estimated or grant-date pay, includes salary, bonus, restricted stock and the estimated value of stock

\footnotetext{
${ }^{1}$ Natalie Singer, April 8, 2012, http://www.nytimes.com/2012/04/08/business/in-chief-executives-pay-a-rich-gameof-thrones.html.

${ }^{2}$ Scott DeCarlo, April 23, 2012, “Gravity-Defying CEO Pay,” http://www.forbes.com/forbes/2012/0423/ceocompensation-12-company-earnings-highest-gravity-defying-pay.html
} 
options when they are granted. This is the compensation package the board has awarded the CEO that year. The second, realized pay, values stock options at their realized values only if and when they are exercised and realized.

In looking at CEO pay levels, I focus on estimated pay because that is the pay under the board's control. Average estimated CEO pay (adjusted for inflation) is at roughly the same level in 2010 as it was in 1998 and lower than it was in 2000. In other words, average CEO pay has not continued to increase. It has declined since the large run up of the 1990s.

While public company CEO pay has declined, it is still very high relative to the typical household. But that also is true of the pay of top performers in other professions such as lawyers, investors, and private company executives.

I extend the analysis in Kaplan and Rauh (2010) to measure average CEO pay relative to the pay of others with top incomes. The ratio of average CEO pay to the average pay of those with top incomes (the top $0.1 \%$ ) is comparable to or lower than the ratios in the early 1990s. And the results in Bakhija et al. (2012) suggest that the pay of public company executives has increased by less than the pay of private company executives since 1980 .

Over the longer-term, the ratio of public company CEO pay to the top 0.1 percent of taxpayers in the late 2000 s is comparable to its level in the late 1930 s as well as the early 1990 s, but higher than its long-term average. ${ }^{3}$ The ratio of large-company CEO pay to firm market value is roughly similar to its level in the late-1970s and lower than its pre-1960s levels.

I also extend the analysis in Kaplan and Rauh (2010) to show the increase in compensation for several particular highly paid groups. Top lawyers have seen their pay increase by roughly the same percentage as S\&P 500 CEOs. Hedge fund, private equity, and venture capital investors have seen their fees increase markedly. The top 25 hedge fund managers as a group regularly earn more than all 500 CEOs in the S\&P 500.

\footnotetext{
${ }^{3}$ See also Murphy (2012) and Frydman and Jenter (2010) for excellent surveys on CEO pay. They show similar time series evidence on CEO compensation.
} 
In other words, while public company CEOs are highly paid, other groups with similar backgrounds and talents have done at least equally well over the last twenty years. If one uses evidence of higher CEO pay as evidence of managerial power or capture, one must also explain why the other professional groups have had a similar or even higher growth in pay. A more natural interpretation is that the market for talent has driven a meaningful portion of the increase in pay at the top. Consistent with this market-determined conclusion, top executive pay policies at over 98\% of S\&P 500 and Russell 3000 companies received majority shareholder support in the Dodd-Frank mandated Say-On-Pay votes in 2011. The 2012 votes have followed a similar pattern.

Second, are CEOs paid for good stock performance? In looking at CEO pay for performance, I look at the relation of realized pay to firm performance. The question is whether CEOs who perform better earn more in realized pay. Kaplan and Rauh (2010) look at actual CEO pay in a given year. Firms with CEOs in the top quintile (top 20\%) of realized pay generate stock returns $60 \%$ greater than those of other firms in their industries over the previous 3 years. Firms with CEOs in the bottom quintile of realized pay underperform their industries by almost $20 \%$ in the previous 3 years. The results are qualitatively similar with performance over the previous five years or previous year. The important question that is harder to answer is whether the extent of that pay for performance is efficient and appropriate given market conditions.

Third, are boards doing their jobs? Kaplan and Minton (2012) study CEO turnover in Fortune 500 companies. Turnover levels since 1998 have been higher than in work that has studied earlier periods. In any given year, one out of 6 Fortune 500 CEOs lose their jobs. This compares to one out of 10 in the 1970s. CEOs can expect to be CEOs for less time than in the past. If these declines in expected CEO tenures since 1998 are factored in, the effective decline in CEO pay since then is larger than reported above.

And the CEO turnover is related to poor firm stock performance - both poor performance relative to the industry and poor industry performance. Jenter and Llewellen (2010) present additional evidence consistent with this conclusion. They find "that boards aggressively fire CEOs for poor performance, and 
that the turnover-performance sensitivity increases substantially with board quality" (boards with more independent directors and more director stock ownership).

Murphy (2012) ends his impressive and detailed survey of executive compensation with the conclusion that "It's complicated." He concludes that executive compensation is affected by the interaction of a competitive market for talent, managerial power, and political factors. That conclusion is hard to disagree with. The data I present here are consistent with that conclusion.

There have been corporate governance failures and pay outliers where managerial power is surely exercised. And the pay levels are very high relative to the typical household. Those undoubtedly are sources of the common perceptions. Political and tax factors likely have contributed to the run up of pay in the 1990s and the decline since then.

At the same time, the average, large sample and long-term evidence is less consistent with the common perceptions, but more supportive of market forces as important determinants of CEO pay levels. CEO pay, in particular, is likely to have been affected by similar forces to those that have led to the increase in incomes at the very top. At the same time, boards have been performing their monitoring function, arguably better today than in previous decades. The positive results of the 2011 (and 2012) SayOn-Pay votes suggest a meaningful role for a competitive market for talent.

This evidence also explains why compensation and the role of boards are likely to remain challenging, if not controversial. At the same time that boards have to make sure to pay well enough to attract and retain executive talent, boards are affected by the accurate perception that pay is high relative to the median household and by the negative publicity from pay and governance outliers.

The rest of this paper details these results and conclusions.

\section{How is CEO pay measured?}

There are two ways to measure CEO and top executive pay. The first measure is the estimated or grant-date value of CEO pay. This includes the CEO's salary, bonus, the value of restricted stock issued, and the estimated value of the options issued to the CEO that year (usually calculated with Black-Scholes, 
a generally accepted formula for valuing options). This is the compensation package the board has awarded the CEO that year and, therefore, the appropriate measure to estimate pay levels and assess board governance.

Estimated pay is not a measure of what the CEO actually gets to take home. The CEO takes his or her salary and bonus, but does not get to cash in the options or the restricted stock. Estimated pay, therefore, is not appropriate for considering whether CEOs are paid for performance. It is interesting and somewhat puzzling that Institutional Shareholder Services (ISS), the prominent proxy advisory firm, uses estimated pay to assess pay for performance. ${ }^{4}$

The second measure is realized or actual CEO pay. This includes the CEO's salary, bonus, the value of restricted stock, and the value of the options the CEO exercised that year. Because it uses actual option gains (not the theoretical values), this second measure is a better measure of the amount of money the CEO actually takes home in a given year. This measure, therefore, is more appropriate for considering whether CEOs are paid for performance. ${ }^{5}$

Realized pay also is not perfect, however, because it includes restricted stock granted in a year as realized pay. In reality, the restricted stock vests over time, so executives cannot sell their restricted stock for several years. As a result, even realized pay may understate the extent to which CEOs are paid for performance.

It also is worth remembering that the realized pay measure does not necessarily include the options granted in just one year. That is, in any given year, a CEO may choose to exercise options granted over many years or may choose not to exercise any options. As a result, realized pay will tend to be more variable than estimated pay.

3. What are the facts about CEO pay?

\footnotetext{
${ }_{5}^{4}$ See Hewitt and Bowie (2011) for ISS's perspective on pay for performance.

${ }^{5}$ Because it measures realized gains, it also includes any benefits from backdating that lowered the exercise price of the options.
} 
In this section, I report time series information on the pay of U.S. CEOs. I begin with the CEOs of S\&P 500 companies from 1993 to 2010 using data from Standard and Poor's ExecuComp database. These are the largest publicly traded U.S. companies with the median S\&P 500 company employing more than 20,000 people. I then report pay for the CEOs of the other companies covered by ExecuComp companies that at one time have been in Standard \& Poor's 1500 index - but are not in the S\&P 500. For both sets of companies I consider estimated and realized pay.

\section{a. S\&P 500 CEOs}

Figures 1 to 4 report information on the pay of S\&P 500 CEOs from 1993 to 2010. The figures show that CEO pay increased significantly from 1993 to 2000. Since 2000, however, average CEO pay has declined. In real terms, pay in 2010 was roughly equal to its level in 1998.

Figure 1 reports the average and median total estimated pay of S\&P 500 CEOs from 1993 to 2010 (in millions of 2010 \$). This is the pay the board expects to give the CEO. Average CEO pay increased markedly from 1993 to 2000 . After peaking in 2000, it has declined by over $46 \%$ since then. Median CEO pay also increased markedly from 1993 to 2000. Median pay peaked in 2001 and has declined slightly since then. The convergence between the means and medians suggest that boards have become substantially less likely to award large and unusual pay packages to CEOs since 2000. Nevertheless, the graphs indicate that boards expected to pay CEOs well. In 2010, the median S\&P 500 CEO received estimated pay of just over $\$ 8.5$ million; the average CEO, pay of just over $\$ 10$ million.

Figure 2 reports S\&P 500 CEO estimated pay relative to median household income. Again, average and median CEO pay peaked in 2000 / 2001. Average CEO pay peaked in 2000 at over 350 times the median household income in the U.S. It has since declined to roughly 200 times. Median CEO pay peaked in 2001 at somewhat over 175 times median household income and has more or less remained 
there since. While these multiples are not as high as some that are quoted by shareholder activists, they remain very high. ${ }^{6}$

Figures 3 and 4 present the analogous figures for actual or realized CEO pay. Recall that this includes exercised options issued in the past. Figure 3 shows that average actual pay also peaked in 2000, dipped by more than $50 \%$ by 2002 , rebounded close to 2000 levels by 2007 , dipped markedly again in 2009 and rebounded somewhat in 2010. Average pay in 2010, at $\$ 11.6$ million, is $35 \%$ below its peak in 2000.

Median pay has continued to increase and peaked in 2006 at a value of just over $\$ 8$ million. The increase in the median is the result of the increased use of restricted stock rather than stock options. Figure 4 shows a similar pattern for average and median realized pay relative to median household income. The average and median S\&P 500 CEO realized, respectively, 234 and 165 times the median household in 2010 .

\section{b. Non-S\&P 500 CEOs}

Figure 5 presents average and median estimated pay for the CEOs of companies in the ExecuComp database that are not in the S\&P 500. Figure 6 compares the average and estimated pay for these CEOs to the income of the median household.

Figure 5 shows that pay for these CEOs, like those in the S\&P 500, increased in the 1990s and declined in the 2000s. The increases and the declines, however, were smaller in magnitude than those for the S\&P 500. Overall, from 1993 to 2010, average pay increased by 54\% for the non-S\&P 500 CEOs compared to $150 \%$ for the S\&P 500 CEOs. Like the S\&P 500 CEOs, average pay levels today are roughly equal to those in 1997 and 1998.

\footnotetext{
${ }^{6}$ For example, as of April 2012, the AFL-CIO website reports that CEO pay in 2010 was 343 times the median worker.
} 
Figure 6 shows that average estimated pay of the non-S\&P 500 CEOs relative to median household income increased from 50 times in 1993 to over 70 times in 1997 and has returned to roughly 70 times as of 2010 from a peak of 90 times in 2001.

Figure 7 reports the average and median realized pay of the non-S\&P 500 CEOs. Average realized pay grew through 2005, dipped markedly through 2009, and rebounded somewhat in 2010. Average pay in 2010 , at $\$ 4.0$ million, is still $20 \%$ below its peak in 2005 , and is roughly $1 / 3$ of realized pay for S\&P 500 CEOs.

Overall, then, these figures show that estimated CEO pay - the pay that boards expected to pay their CEOs - peaked in $2000 / 2001$, both for S\&P 500 and non-S\&P 500 CEOs. Since then, average estimated CEO pay has declined, returning to roughly the level it was in 1997 and 1998.

Nevertheless, there are still outliers on estimated pay that seem more consistent with managerial power. In 2010, eight CEOs earned over $\$ 30 \mathrm{M}$; three earned over $\$ 50 \mathrm{M}$. Interestingly, those three the CEOs of CBS, Oracle and Viacom - are controlled by their large shareholders, Sumner Redstone, Larry Ellison and Sumner Redstone, respectively.

4. How does CEO pay compare to that of other highly paid people?

Although estimated CEO pay has declined in the last ten years, it is clear that CEOs are highly paid and have done very well since the early 1990s. The important question is why they have done so well? Are the high pay levels due to the managerial power of CEOs over their boards? Are those pay levels driven by a competitive market for talent? Or have other factors been important?

Gabaix and Landier (2008) argue that market forces explain the increases in CEO pay. In a simple competitive model, they show that as firms get bigger, CEOs will get paid more. A talented CEO creates more value as a firm becomes larger. In a competitive market, CEO pay will be bid up as firms become larger. Larger average firm size increases the returns to hiring a more productive CEO. They find empirically that increase in CEO pay since 1980 can be fully attributed to the increase in large company market values. 
Frydman and Saks (2010) study top executive pay from the 1930s to 2005. They, too, conclude that the evidence is not consistent with the managerial power / rent extraction story. Yet their results call into question the story in Gabaix and Landier (2008) because CEO pay did not increase with firm market value before 1970 and because changes in firm size explain less of the variation in changes in compensation.

Both Gabaix and Landier (2008), Frydman and Saks (2010) as well as Murphy and Zabonjik (2008) focus on the market for top executives of public companies. But the same people also can become executives at private companies, become (or remain) consultants, and, earlier in their careers, become lawyers, investment bankers, and investors. In a competitive market for talent, similarly talented individuals should have done as well as CEOs over the last 20 or 30 years.

That is indeed what has occurred. Piketty and Saez (2003 and 2006a) show that the share of pretax income earned by very high earners - the top $1 \%$ or top $0.1 \%$ - has increased markedly over the last thirty years. Figures 8 and 9 reproduce their income shares for the top $0.1 \%$ from 1914 to 2010, and the more recent period from 1989 to 2010 . The pattern in figure 9 shows roughly the same patterns as those for CEO pay in figures $1,3,5$ and 7 .

In Kaplan and Rauh (2010), Josh Rauh and I compared how well off CEOs and top executives were in 2004 (the most recent year with good data available when we wrote the paper) compared to 1994 (the first year in which good data were available) relative to other top earners. Figure 10 updates this analysis by comparing the average estimated pay of S\&P 500 CEOs to the average pay of U.S. taxpayers in the top $0.1 \%$ from 1993 to 2010 . In 2010, the AGI cutoff for the top $0.1 \%$ was $\$ 1.5$ million; the average AGI for taxpayers in the top $0.1 \%$ was $\$ 4.9$ million. Because there are roughly 140,000 such taxpayers, the $500 \mathrm{~S} \& \mathrm{P} 500 \mathrm{CEO}$ s have only a minimal effect on the average AGI of this group.

Consistent with Kaplan and Rauh (2010), 2010 pay for S\&P 500 CEOs relative to the average income of the top $0.1 \%$ in 2010 is about what it was in 1994 . On a relative basis, estimated pay increased markedly from 1993 to 2001, then declined markedly from 2001 to 2007 . In fact, of the 18 years in the 
sample, the ratio is the lowest in 2007. In other words, S\&P 500 CEOs have seen little change in their estimated pay relative to the top $0.1 \%$ since the early 1990 s.

Figure 11 repeats the same analysis for estimated pay for non-S\&P 500 CEOs. In every year, the average non-S\&P 500 CEO earns less than the average taxpayer in the top $0.1 \%$. The ratios in every year from 2005 to 2010 are lower than the ratios before 1998. Non-S\&P 500 CEOs are worse off in their estimated pay relative to the top $0.1 \%$ than they were in the early- and mid- $1990 \mathrm{~s}$.

Over the last twenty years, then, the period in which the level of estimated CEO pay increased markedly, CEO pay relative to the top $0.1 \%$ has remained relatively constant or even declined. This result is consistent with a competitive market for talent. On the other hand, if one uses evidence of higher public company CEO pay as inherent evidence of managerial power or rents, one must explain why others in the very top income groups not subject to managerial power effects have seen a similar growth in pay.

The greater puzzle in these figures is why estimated CEO pay increased so much at S\&P 500 firms from 1993 to 2001 and declined so much for both from 2001 to 2007, both in real terms and relative to the top $0.1 \%$. Murphy (2012) rejects the simple managerial power explanation for these patterns for several reasons. First, there is no evidence boards have become weaker over time. In fact, most evidence suggests the opposite. Second, the largest increases in pay go to CEOs hired externally, from outside the company. These CEOs are hired in arms-length negotiations with boards over whom they have no power initially. Third, as we saw above, the price of alternative talent increased significantly.

Instead, Murphy (2012) attributes the large run-up in CEO pay (particularly option-based pay) in the 1990s not to managerial power, but to four different forces. First, boards were responding to increased shareholder pressure for equity-based pay. Second, Bill Clinton and Congress passed Section 162(m) of the tax code that permitted public companies to deduct top executive pay if that pay was tied to performance. Options qualified for the deduction. Third, the Financial Accounting Standards Board did not require companies to expense options for accounting purposes as long as the strike price of the options equaled the company's grant date share price. Because most option grants, therefore, had no 
income statement cost, many boards undervalued or misperceived the true cost of issuing options.

Fourth, the misperception led many companies to award the same number of options each year (rather than the same value). As stock prices increased markedly in the 1990s, the value of those options increased markedly as well. These four forces fueled the run-up. The run-up reversed after 2000 because of a backlash from the Internet bust, because companies increasingly expensed options (and were required to do so by 2006), and because of stricter rules on option plans from the NYSE and NASDAQ. I am sympathetic to those explanations, particularly for the S\&P 500 CEOs.

Figures 12 and 13 report the analogous analyses for realized pay. Since 1997, realized pay of S\&P 500 CEOs has been stable at 2 to 2.5 times the average pay of the top $0.1 \%$. From 1993 to 1996 , realized pay was somewhat lower, at roughly 1.75 times. At the same time, average pay of non-S\&P 500 CEOs has varied from 0.6 to 0.8 times the average pay of the top $0.1 \%$ since 1994 with no obvious trend. The ratio was relatively low in 2007 and 2008 at roughly 0.6 and relatively high in 2010 at roughly 0.8 . Overall, one concludes that the ratios have remained relatively stable for both sets of CEOs. Again, there is little evidence that the CEOs have been particularly better off than others in the top $0.1 \%$.

\section{What has happened to CEO turnover?}

The previous analyses look at how CEO pay has changed over time. The analyses implicitly assume that other aspects of the CEO job have not changed. In particular, the analyses and the calculations of estimated pay implicitly assume that CEO tenures have not changed. This turns out not to be the case.

Bernadette Minton and I study CEO turnover in Fortune 500 firms from 1992 to 2007 in Kaplan and Minton (2012). ${ }^{7}$ We consider all turnover, both internal and turnover that occurs through takeover (primarily) and bankruptcy. We find that turnover levels since 1998 are substantially higher than turnover levels from 1992 to 1997 and substantially higher than in previous work that has studied previous periods.

\footnotetext{
${ }^{7}$ The results are virtually the same for S\&P 500 firms.
} 
In the 1970s and 1980s, Murphy and Zabonjik (2008) find that roughly 10\% of CEOs turned over each year, not counting takeovers. Kaplan and Minton (2012) find a similar percentage, $10.2 \%$, for large company CEOs from 1992 to 1997. Since 1998, however, turnover has increased meaningfully. Not counting takeovers, $12.4 \%$ of CEOs turned over each year, on average, from 1998 to $2003 ; 12.2 \%$ of CEOs turned over each year, on average, from 2004 to 2010. Figure 14 updates the Kaplan and Minton data through 2010 and reports it graphically.

When takeovers are included, the changes are greater. From 1992 to 1997, total CEO turnover averaged 13.0\%; from 1998 to 2003, total turnover averaged $17.6 \%$; and from 2004 to $2010,15.8 \%$.

Since 1998, then, an average of $16.6 \%$ of CEOs of Fortune 500 companies lose their jobs each year. This means the average CEO can expect to have the CEO job for roughly 6 years. In the early 1990s, expected CEO tenure was closer to 8 years. In the 1970s, when there were few takeovers, expected tenure was closer to 10 years.

The decline in tenure implies that the CEO job has become riskier over time. Comparing CEO pay in the 2000s to CEO pay in the 1990s (and earlier), then, is not an apples-to-apples comparison. The shorter expected tenure offsets some of the benefit of the increase in CEO pay over this period. For example, if a CEO earns CEO-like pay for only six years instead of eight and earns markedly less if he or she retires, the reduced tenure would effectively represent a $25 \%$ reduction in expected pay.

Peters and Wagner (2012) estimate this explicitly. They find "a robust and significantly positive association between predicted turnover risk and CEO compensation." In their paper, a 1\% increase in turnover risk is associated with a $10 \%$ increase in pay. If turnover has increased by $2 \%$, then riskadjusted pay should have increased by $20 \%$.

Taking this seriously, CEO pay in 2010 in figures 1-7 and 10-13 would need to be reduced by at least $20 \%$ relative to CEO pay before 1998 . This would make the decline in real CEO pay and CEO pay relative to others in the top $0.1 \%$ even greater that described above.

In other words, CEOs have done relatively worse compared to their early 1990s counterparts than the compensation figures alone would suggest. 
6. What about the longer term?

As mentioned earlier, Frydman and Saks (2010) and Frydman and Jenter (2010) consider long run patterns of large company CEO pay. Frydman and Saks (2010) conclude that "the long-run trends in pay seem inconsistent with explanations related to managerial rent seeking." At the same time, they also conclude that the firm scale explanation of Gabaix and Landier (2008) who "predict that compensation should correlate 1-to-1 with the growth in the size of the aggregate value of firms," is unsuccessful before 1970.

In this section, like Frydman and Saks (2010), I compare a long time series of estimated CEO pay with firm size. I obtain similar results to theirs. I also compare that times series of estimated CEO pay with the average pay of the top $0.1 \%$. Here the results are somewhat different. Over the long-term, estimated CEO pay has moved with the pay of the top $0.1 \%$. This also suggests an important competitive market component for CEO pay over the long-term.

To look at CEO pay over the long-term, I staple together three data sets. First, I use the ExecuComp data for S\&P 500 CEOs from 1992 to 2010. Second, from 1980 to 1992, I use the means of estimated pay for large company CEOs in Hall and Leibman (1998). The Hall and Leibman data come from roughly 400 firms that are on the Forbes 500 lists of large public companies in the 1980s. Like the S\&P 500 companies, these are representative of large public companies. (Hall and Leibman present estimates from 1980 to 1994.) To make them comparable, I index the Hall and Leibman numbers to the 1992 ExecuComp numbers. That is, I calculate 1991 pay as the 1992 ExecuComp pay changed by the percentage change in the Hall and Leibman pay numbers from 1991 to 1992 . The percentage pay changes in Hall and Leibman from 1992 to 1994 of $2 \%$ and $21 \%$ are similar to the percentage pay change in ExecuComp of $1 \%$ and $24 \%$ for those years, suggesting the sample firms are similar. 
Third, from 1936 to 1980, I use the annual means of estimated pay from Frydman and Saks (2010). ${ }^{8}$ The Frydman and Saks data come from the largest 50 publicly-traded companies in 1940, 1960 and 1990 that they follow over time. They argue that these data also are representative of a group of large companies.

The resulting series is somewhat different from Frydman and Saks (2010) who show a larger increase in pay over time. The reason is that the average increase in CEO pay in Frydman and Saks (2010) from 1980 to 1994 data is substantially larger (289\%) than the average increase (209\%) in the Hall and Leibman data; the Frydman and Saks increases also are much greater than those reported by Murphy (2012) for the 1980s.

Figure 15 shows the ratio of average CEO pay to the average stock market value of the top 500 publicly traded companies according to the Center for Research in Security Prices (CRSP). I report the ratio multiplied by 1,000 . The figure shows that CEO pay was a much higher fraction of market value in the 1930s and 1940s than it was in the 1960s. Figure 16 shows that today, the ratio is similar to its level in the late 1970s and the late 1950s. Through 1960, market values increased much more than CEO pay. The growth rates of market values continued to exceed pay in the 1960s, but pay caught up again by the late 1970s. The ratios increased modestly through 2000 , and have declined since, returning to their late 1950s levels. The data, then, seem supportive of the Gabaix and Landier (2008) prediction about the positive relationship between firm size and CEO pay since the late 1970s, but not before.

Figure 17 shows average CEO pay in 2010 dollars and the ratio of CEO pay to the average pay of the top 0.1 percent from 1936 to 2010 . Figure 18 shows only the ratio. While average pay has increased markedly in the last 30 years, the ratio of pay to the top 0.1 percent has increased by much less. The ratio increased from the mid-1980s to the turn of the century. Since then, it has declined, although it remains above its historical average and the level in the mid-1980s. Interestingly, the ratio in 2007 was lower than the ratio in the late 1930s when dispersed shareholdings and problems of managerial power were presumably less acute than they are today. The ratio today is modestly higher than in the late 1930s.

\footnotetext{
${ }^{8}$ I thank Carola Frydman for providing them.
} 
The unanswered question, then, is to explain what drove the ratio so high from the early 1980 s to the early 2000s and has led to its decline since then. Murphy and Zabonjik (2008) and Frydman (2007) argue that part of the increase since the 1980s can be explained by a movement towards CEOs with more general skills and a more competitive labor market. In particular, Murphy and Zábojník (2008) attribute the increase in executive pay to the increased prevalence of hiring CEOs from outside the firm.

Nevertheless, Murphy (2012) doubts that such changes can explain the increase in pay levels in the late 1990s. As mentioned above, it is likely that government policies and regulations played an important role. In addition, Holmstrom and Kaplan (2001) and Murphy (2012) both suggest that the relatively low pay of CEOs at the start of the 1980s was suboptimal at the start of the 1980s.

In summary, taken together, Figures 15 to 18 suggest that a combination of firm scale and the market for talent are associated with a meaningful amount of the movement of large company CEO pay over time.

7. How do CEOs compare to other highly paid groups?

In this section, I present more detailed evidence on how other groups - non-public company executives, lawyers, investors, investment bankers and athletes - in the top income brackets have fared over the last twenty or thirty years relative to public company CEOs.

\section{A. Other Executives}

Bakija Cole Heim (2012) study IRS tax return data for a number of years between 1979 and 2005. They are able to distinguish among taxpayers who were employed as business executives, financial executives, lawyers, and in medicine.

Figure 19 looks at taxpayers in the top $0.1 \%$ of AGI and reports the percentage of total AGI contributed by those taxpayers in the four groups. The figure shows that the percentage of AGI from executives in the top $0.1 \%$ increased from $1.5 \%$ in 1979 to $3.0 \%$ in 1993 to over $4.5 \%$ in 2005 . Taxpayers in finance increased from $0.4 \%$ in 1979 to $0.9 \%$ in 1993 to over $2.0 \%$ in 2005 . These 
increases compare to income shares of all top $0.1 \%$ taxpayers of $3.4 \%$ in 1979 to $5.7 \%$ in 1993 to $11.0 \%$ in 2005 . The share of the top $0.1 \%$, then, increased by a factor of more than three times. Executives increased their shares by roughly the same factor of three times while taxpayers in finance increased their share by a factor of five times. The larger relative increase in finance is consistent with the results and arguments in Kaplan and Rauh (2010) and Philippon and Reshef (2008) that financial executives did particularly well over this period.

Bakija at al. cannot identify whether the executives in their sample work for private or public companies, or whether the taxpayers are CEOs or not. They try to distinguish between public and private company CEOs by comparing executives who receive the majority of their income in salary and wages from those who receive the majority of their income from self-employment, partnership and S-corporation related income not salary and wages. They argue that the former are more likely to include public company executives while the latter are most likely to include executives of closely-held business. Bakija et al. also distinguish among executives, managers, and supervisors. In the figure below, I combine those three groups. The conclusions and patterns are similar if I look only at executives.

Figure 20 is the key graph from the Bakija et al. data. It indicates that the pay of executives of closely-held businesses increased by more than the pay of salaried executives from 1979 to 1993 and, again, from 1993 to 2005 . Figure 21 shows that closely-held executives comprised roughly $22 \%$ of the top $0.1 \%$ in 2005 , up from $18 \%$ in 1993 and $9 \%$ in 1979 . At the same time, salaried executives comprised $20 \%$ of the top $0.1 \%$ in 2005 down from $28 \%$ in 1993 and $38 \%$ in 1979.

Public company executives, those who should be more subject to problems of managerial power problems, saw their pay and relative standing increase less over this period than executives of closelyheld company businesses that are, by definition, controlled by large shareholders or the executives and are subject to limited agency problems. This is notable because many of the salaried and closely-held executives, likely come from the same general executive pool and, presumably, can move between public company and private company employment. Again, if one uses evidence of higher public company executive pay as inherent evidence of capture or managerial power, one has to explain why private 
company executives and the other professional groups have had a similar or higher growth in pay where managerial power concerns are largely absent.

\section{B. Lawyers}

Lawyers at top law firms are another useful comparison group for CEOs. Much of the work these lawyers perform is for corporate clients. Because the law firms are partnerships and their fees are negotiated in an arms-length manner with clients, partner pay at those law firms is arguably market-based and not subject to managerial power concerns. It also is arguably the case that top lawyers are drawn from a similar undergraduate pool as top public company executives.

Lawyers at top law firms also are interesting because the general counsels of large public companies are often former law partners. Accordingly, there is some overlap in the market for talent between top executives and top lawyers.

Figure 22 reports average profit per partner at the 50 top law firms from American Lawyer surveys from 1994 to 2010 . This calculation measures the total partner profits at all of these firms divided by the total number of partners. (The average of the profits per partner at each firm are slightly higher.) The average profit per partner provides an estimate of the average partner's AGI earned from employment at his or her law firm. The average profit per partner increased from \$0.7 million in 1994 to almost \$1.6 million in 2010 (in 2010 dollars). Figure 23 shows that the average profit per partner increased from 10 times median household income to 30 times over this period. Figure 24 shows the average partner's income increased from roughly 0.25 to between 0.30 and 0.35 of the average income of the top $0.1 \%$. Figure 25 shows that estimated pay of the average S\&P 500 CEO was roughly six times that of the average law partner in 1994 and remains roughly six times today after diverging in the late 1990s. Finally, figure 26 shows that estimated pay of non-S\&P 500 CEOs has declined from 3 times the average top 50 law firm partner to 2 times. In other words, the average S\&P 500 CEO and the average top 50 law firm partner have done roughly as well over the last twenty years. The lawyers have done relatively better than non-S\&P 500 CEOs. 
These numbers may understate how well the very top partners at these law firms have done. That is because the number of partners increased over this period from 7,000 to 12,000 (i.e., the averages went up quite a bit, but so did the number of partners). If it were possible to compare the pay of the top 7,000 partners in 2010 and 1994, just as it is possible to compare the pay of the 500 S\&P 500 CEOs, it is likely that the increase for the top lawyers would be greater.

On the whole then, top corporate law partners have seen their percentage pay increase over the last 20 years by at least as much as public company CEOs. The profit of law firms (and the pay of corporate lawyers) is set by arms-length or market negotiations. Again, this is consistent with an increase in the market value of talent.

\section{Hedge Fund Managers}

Top hedge fund managers are another highly paid group. Since 2001, Absolute Return and Alpha (AR) magazine has published an annual "Rich List" of the 25 highest paid hedge fund managers. AR estimates the annual income of these managers from fees and their capital invested in their funds. As a result, AR overstates the income of these managers attributable to their employment per se, as separate from their investment income. Nevertheless, the results are striking.

Figure 27 reports the average income of these hedge fund managers (in millions 2010 dollars). The average peaked at over $\$ 1$ billion in 2007 and was as low as $\$ 134$ million in 2002. These are much higher than the averages for S\&P 500 CEOs.

Figure 28 puts this into perspective. It compares the combined incomes of the 25 highest paid hedge fund managers to the combined estimated pay of the 500 S\&P 500 CEOs from 2001 to 2011. From 2001 to 2004, the ratio was roughly 1.0, implying that 25 hedge fund managers earned roughly as much as 500 CEOs. Since 2004, however, the ratio has grown substantially. In 2010, the 25 hedge fund managers earned roughly four times as much as the 500 S\&P 500 CEOs. In other words, hedge fund managers appear to have done considerably better than CEOs over this period. 
Consistent with these figures, the most recent Forbes 400 list includes at least 26 hedge fund managers with 10 among the top 100 richest Americans. At the same time, the list does not include one public company CEO who earned most of his or her equity when the company was public. There are two non-founder public company CEOs among the top 100, Steve Ballmer and Eric Schmidt, but both received most of their equity before their companies went public.

\section{Private Equity Investors}

Kaplan and Rauh (2010) document a large increase in fees to private equity (PE) and venture capital (VC) investors through 2005. Since 2005, the assets under management in private equity have increased substantially.

Figures 29 and 30 calculate the fees and document their growth in two ways. Both figures assume private equity and venture capital investors earn fees on capital raised over the latest seven years. Capital raised or committed is obtained from Private Equity Analyst.

Figure 29 assumes that the PE firms earn a 1.5\% management fee on that capital; VC firms earn a $2.0 \%$ management fee. In addition, figure 29 assumes that $\mathrm{PE}$ and $\mathrm{VC}$ firms receive $20 \%$ of the profits earned by funds in a given year. Profits are estimated using the average return earned by PE and VC funds in a given year reported by Cambridge Associates. This calculation likely understates fees because it assumes that all funds earn the average annual return. Because the $20 \%$ profit share is applied only to positive returns, any dispersion across funds such that some funds earn negative returns implies that the actual profit share exceeds the estimates above.

Figure 30 simply assumes that PE firms earn overall fees of $4 \%$ while VC firms earn fees of 5\% on capital raised over the previous seven years. This assumes that the profit share has a value of roughly $2.5 \%$ per year for PE firms and 3\% per year for $\mathrm{VC}$ firms. Those assumptions are consistent with treating the profit share as a call option on the funds with volatility of estimates $28 \%$ and $35 \%$, respectively for PE and VC funds. The 4\% and 5\% assumptions also are consistent with the fee estimates in Metrick and Yasuda (2010). 
Figure 29 shows that fees to PE firms have increased substantially over time. Since 2005, they have averaged roughly $\$ 34$ billion per year in 2010 dollars. This represents an increase of almost three times the average over the previous ten years. Figure 30 estimates PE firm fees at roughly $\$ 26$ billion per year since 2005. Under both sets of assumptions, estimated fees in 2010 have increased by a factor of five to eight times since 1993.

Consistent with this growth in fees, a number of private equity investors regularly show up in the Forbes lists of billionaires and wealthy Americans. The most recent Forbes 400 of the wealthiest Americans included at least 25 members who earned their wealth through PE and VC funds.

Venture capital investors have had a more volatile record. Their fees peaked around the internet boom at the turn of the century with estimated fees in figure 29 exceeding $\$ 70$ billion in 2000 . Nevertheless, both figures 29 and 30 suggest that fees have increased by a factor of six times since 1993.

\section{E. Athletes}

Kaplan and Rauh (2010) also compare CEO pay to that for professional athletes in baseball, basketball, and football in 1995 and 2004. I extend that analysis by looking at the average pay of the top 25 most highly paid athletes in those sports.

Figure 31 reports those averages for baseball, basketball, and football in every other year from 1993 to 2011. Pay at the top has increased markedly for the athletes since 1993, with baseball, basketball and football players earning, respectively 2.5, 3.3 and 5.8 (based on 2009) times as much today as in 1993.

Figure 32 compares average estimated pay for S\&P 500 CEOs relative to the average pay of the athletes. The figure shows that in 2010 compared to 1993, the S\&P 500 CEOs have done roughly as well as the top baseball players, but not so well as the basketball and football players.

F. Summary 
The point of these comparisons is to confirm that while public company CEOs earn a great deal, they are not unique. Other groups with similar backgrounds - private company executives, corporate lawyers, hedge fund investors, private equity investors and others- have seen significant pay increases where there is a competitive market for talent and managerial power problems are absent. Again, if one uses evidence of higher CEO pay as evidence of managerial power or capture, one must also explain why these other professional groups have had a similar or even higher growth in pay. It seems more likely that a meaningful portion of the increase in CEO pay has been driven by market forces as well.

What are those market forces? In Kaplan and Rauh (2010), Josh Rauh and I argued that some combination of changes in technology along with an increase in the scale of enterprises and finance have allowed more talented or fortunate people to increase their productivity relative to others. This seems relevant for the increase in pay of lawyers and investors (technology allows them to acquire information and trade large amounts more efficiently) as well as CEOs (technology allows them to manage very large global organizations). This suggests that increases in incomes at the top have been driven more by technology and scale, than by poor corporate governance. ${ }^{9}$ Under this view, as firms have become more valuable and technology increasingly has allowed CEOs to affect that value, boards have responded by spending more to attract and motivate talent.

8. What do boards do? Are they controlled by their CEOs?

According to the managerial power story, managers control their boards and the boards are too friendly to management: boards do not pay for performance and boards do not fire CEOs for poor performance. This section considers the evidence for that.

A. Are CEOs paid for performance?

\footnotetext{
9 See Parker and Vissing-Jorgensen (2010) for a concurring view.
} 
Critics contend that CEOs are not paid for good stock performance. For example, Gretchen Morgenson wrote recently for the New York Times, "Many corporate boards talk a good line about paying for performance. Then they turn around and award fat paychecks to chief executives who, by many measures, don’t deserve them."10

On average, that is not the case. In some cases, the critics confuse estimated pay - what the boards give to the CEOs as estimated pay - and realized pay. The key question is whether CEOs who perform better earn more in realized pay.

For each year from 1999 to 2004, Kaplan and Rauh (2010) took all the firms in the ExecuComp database and sorted them into five groups based on size (assets). We did this because it is wellestablished that pay is tied to firm size. Bigger firms pay more. Within each size group for each year, we sorted the CEOs into five groups based on how much compensation they actually realized. We then looked at how the stocks of each group performed relative to their industry over the previous three years. (The results are qualitatively and statistically identical if we use one year or five years.)

Figure 33 presents the results. Realized compensation is highly related to firm stock performance. Firms with CEOs in the top quintile of actual pay are the top performing quintile relative to their industries in every size group. Firms with CEOs in the bottom quintile of actual pay are the worst performing quintile relative to their industries in every size group. And the magnitudes of the performance differences are large. These calculations understate actual pay for performance because they value restricted stock at grant date values. In reality, executives do not get to sell their stock at those values. At a minimum, they have to wait several years until the restricted stock vests. As a result, the values actually realized will be further tied to stock performance.

Figure 34 graphs the level of the S\&P 500 index against average realized CEO pay for S\&P 500 CEOs. As there is in the cross-section, there is a strong relation between realized pay and stock performance in the time series.

\footnotetext{
${ }^{10}$ Gretchen Morgenson, April 8, 2012, www.nytimes.com/2012/04/08/business/say-on-pay-votes-make-moreshareholder-voices-heard.html?
} 
Similarly, Frydman and Saks (2010) study the correlation between executive's wealth and firm performance. They find that CEO wealth has been strongly tied to firm performance since the 1930s and that relationship has "strengthened considerably" (p. 2100) after the mid-1980s.

The evidence, then, is consistent with realized CEO pay and CEO wealth being strongly tied to firm performance. In their surveys, Frydman and Jenter (2010) and Murphy (2012) reach similar conclusions. They calculate an "equity at stake" that measures the change in CEO wealth from a 1\% change in stock price. Murphy (2012) reports that the equity at stake for the median S\&P 500 CEO is almost $\$ 600,000$ in 2010 and has been at that level or higher in all but one year since 1998. Frydman and Jenter (2010) conclude that the "long run evidence shows that compensation arrangements have served to tie the wealth of managers to firm performance — and perhaps to align Managers' with shareholders' interests - for most of the twentieth century." Murphy (2012) also reports that CEOs have a large amount of wealth tied to firm performance.

The more difficult question is how much pay-for-performance is optimal and whether the current practices can become more efficient. Some argue that pay-for-performance should be increased, while others argue that pay-for-performance incentives, particularly in financial services, should be lower.

Pay for performance is also criticized because pay is based on absolute or actual performance rather than performance relative to a firm's industry. ${ }^{11}$ In other words, CEOs and executives are paid to some extent for general economic conditions or luck.

Some critics also point out that CEOs of large companies who do not perform well are still paid a great deal. This, too, is complicated. CEO's of S\&P 500 companies, almost by definition, have been very successful over their careers and have opportunity costs. CEOs are paid well on average because they have other opportunities, the CEO job is riskier and less certain than in the past, and the typical S\&P 500 company is a large and complicated entity with more than 20,000 employees. But, while CEOs who perform poorly are paid less than CEOs who perform well, poorly performing CEOs are still paid well relative to the average worker or household. An analogy is two lawyers in a corporate trial. The

\footnotetext{
${ }^{11}$ For example, see Bebchuk and Fried (2006), Bertrand and Mullinaithan (2001) and Zingales (2012).
} 
companies will hire the best lawyers they can find. The lawyers will get paid well. Yet, one side will win and one side will lose. That does not mean that the lawyers on the losing side have no opportunity cost and should not be paid for the trial or for future trials.

\section{B. Are CEOs fired for poor performance?}

Critics contend that boards are too friendly to management. As described earlier, Kaplan and Minton (2012) find that CEO turnover has increased measurably since the mid-1990s. Kaplan and Minton (2012) also consider how that turnover varies with firm performance. We find that turnover is significantly higher when firm performance is poor.

We divide firm performance into performance of the firm's industry and performance relative to the industry. We find that board-driven CEO turnover is strongly related to both. CEOs are more likely to lose their job when their firms perform poorly relative to the industry and when their industries perform poorly. And the relationships are meaningful. These relations are stronger from 1997 onward suggesting that CEO incentives have become more linked to performance over time, not less.

The Kaplan and Minton results suggest that since 1998, annual CEO turnover is higher than at any time since 1970 . The job is riskier. And, turnover initiated by the board is significantly related to industry stock performance and firm stock performance relative to the industry. That is, CEOs face significant performance pressure.

Jenter and Llewellen (2010) present additional evidence consistent with this conclusion. They look at CEO turnover in the 1,600+ firms in the ExecuComp database from 1992 to 2004 . They find "that boards aggressively fire CEOs for poor performance, and that the turnover-performance sensitivity increases substantially with board quality." In the first five years of tenure, CEOs who perform in the bottom quintile are $42 \%$ more likely to depart than CEOs in the top quintile. This spread increases to more than 70 percentage points for firms with high quality boards." (Higher quality boards have more independent directors and more director stock ownership.) Their results are shown graphically in figures 35 and 36. 
As with pay-for-performance, the more difficult question is whether these differential departure rates are optimal and whether the current practices can become more efficient. See Taylor (2010) for an attempt at estimating this.

9. What do shareholders think?

It would be useful to know what shareholders think of all this. Fortunately, the Dodd-Frank Wall Street Reform and Consumer Protection Act of 2010 mandated that all firms with more than \$75 million in publicly-traded stock hold an advisory (i.e., non-binding) shareholder vote on the compensation of the top five executives. These votes are known as Say-on-Pay (SOP) votes. The law went into effect for proxy votes in 2011. According to Thomas et al. (2011), the legislative supporters of the provision believed that by increasing shareholder power, the SOP vote would reduce the CEO pay spiral and link pay to performance. This is more or less the view of those who take the managerial power position that CEOs have captured the pay process. Under the alternative view, that pay levels and pay-forperformance are largely determined in a competitive market, SOP votes would be a non-event. The SOP votes, therefore, set up a useful test of the managerial power view versus the view that the market for talent determines executive compensation.

The results of these votes in 2011 overwhelmingly favored existing pay policies. Equilar (2011) reported that only 38 of 2,252 companies or fewer than $2 \%$ received less than a majority of favorable votes. Over $98 \%$ received majority support. Only 165 , or fewer than 8 percent, received a favorable vote of less than $70 \%$ of the voting shareholders. ${ }^{12}$ At the same time, 1,654 companies, or more than $73 \%$, received a favorable vote of more than $90 \%$ of the voting shareholders. The results were similar at larger companies, with pay policies receiving shareholder approval at over $98 \%$ of S\&P 500 companies. Figures 37 and 38 report these results graphically.

\footnotetext{
${ }^{12}$ Mishra (2012) reports that 182 of 2,500 firms, or 7.3 percent, received a favorable vote of less than 70 percent.
} 
Those levels of approval do not appear to be a one-year phenomenon. At the time this paper went to press in the summer of 2012, more than 1,400 firms had held their annual shareholder vote for the year, and those votes followed a qualitatively similar pattern.

The few companies that did not receive majority support as well as some of the companies with a substantial minority of no votes suggest that some CEOs exert managerial power. But they appear to be the exceptions. And the no votes from shareholders highlight those exceptions and put pressure on boards to fix them.

At the same time, the positive shareholder votes for most companies seem inconsistent with the view the CEO and top executive pay are driven largely by managerial power. Rather, the votes are consistent with a more market-based view of top executive pay for the typical company.

10. What can we learn from private equity investors?

In Kaplan (2008), I noted that the movement of public company CEOs to work for private equity firms and private equity funded companies was consistent with a competitive market for executives. Private equity investors are strongly motivated to make profits. Any extra compensation to a CEO reduces the profit of a private equity investor. In addition, private equity investors control the boards of their firms, so the negotiations between boards and CEOs are at arms-length. If public company executives are overpaid for what they do, one would not expect executives to leave those public companies.

Cronqvist and Fahlenbrach (2011) study changes in the design of CEO contracts for publiclytraded firms that are taken private by private equity investors. They do not find any evidence that private equity sponsors reduce base salaries, bonuses, and perquisites. They interpret this as suggesting that CEO pay levels in public companies are not excessive.

Cronqvist and Fahlenbrach (2011) find that private equity investors - like public companies - use subjective performance evaluation, time-vesting equity, and do not condition vesting on relative industry performance. That is, CEOs of private equity funded companies (with very concentrated ownership) are 
compensated for performance that is outside of the control of the CEO (e.g., an oil firm's profits increase owing to an increase in the price of oil or to another positive industry shock). This is worth mentioning given the criticism mentioned earlier that public company executives are paid for luck. If relative performance evaluation were meaningfully more efficient, we would expect to see private equity investors make more use of it.

At the same time, Cronqvist and Fahlenbrach (2011) find that the contracts make less use of earnings-based and non-financial measures; greater use of equity grant performance-vesting based on prespecified performance measures; and require terminated CEOs to forfeit unvested equity. These last results suggest that private equity firms implement greater pay-for-performance than public company investors. If this is the case, it suggests one area where public company boards can do better.

11. How have public companies in the U.S. performed?

In Kaplan (2008), I argued that the U.S. economy and, particularly, the U.S. corporate sector, had performed well in the previous fifteen years or so, the period in which corporate governance and CEO pay have been criticized. During that period, the productivity of the U.S. economy increased substantially, both on an absolute basis and relative to other developed countries. ${ }^{13}$ Furthermore, the U.S. stock market had performed well.

Since I wrote that in early 2008, the U.S. economy has gone through a financial crisis and recession. The S\&P 500 has declined from a peak of 1576 in 2007 to roughly 1350 as this is being written. At the same time, as we saw earlier, CEO pay has declined. What has happened to the operating performance of the S\&P 500?

Scott Thurm of the Wall Street Journal recently reported that S\&P 500 firms have weathered the financial crisis surprisingly well, with revenues up and debt levels down since $2007 .{ }^{14}$ This performance

\footnotetext{
${ }^{13}$ See Jorgenson et al. (2008) and van Ark et al. (2008).

${ }^{14}$ See "For Big Companies, Life Is Good," Scott Thurm, Wall Street Journal, April 8, 2012.
} 
also is consistent with reports that U.S. companies hold large amounts of cash in 2011. Figures 38 and 39 confirm these results.

Figure 39 reports median operating margins (EBITDA to Sales), net debt (total debt net of cash) to total assets, and cash to total assets for the S\&P 500 from 1993 to 2011. (The figure uses medians because outliers make averages difficult to interpret.) Median margins increased from 1993 to 2007. They increased again, to their highest level in the period, from 2007 to 2011 . Net debt declined from 1993 to 2005, increased from 2005 to 2008 , and has declined to 2006 levels in 2011. Cash holdings have generally increased from 1993 to 2009, and declined slightly since then. Figure 38 shows a picture of successful operating performance at S\&P 500 companies since 1993 and, again, from 2007 to 2011.

Figure 40 reports median annual sales and EBITDA growth for S\&P 500 companies from 1993 to 2011. Except in 2001 and 2009, EBITDA at the median S\&P 500 company has grown. On average, median EBITDA has grown $7.3 \%$ per year. The median company in the S\&P 500 in 2007 increased its revenues by almost $9 \%$ and its EBITDA by almost 14\% from 2007 to 2011, despite the financial crisis and recession. The performance of non-financial companies in the S\&P 500 has been stronger.

\section{Summary and Implications}

This paper considers the evidence for three common perceptions or criticisms of U.S. CEO pay and corporate governance: (1) CEOs are overpaid and their pay keeps increasing; (2) CEOs are not paid for performance; (3) boards do not penalize CEOs for poor performance. The evidence is somewhat different from the perceptions.

While average public company CEO pay increased substantially through the 1990s, it has declined since then. CEO pay levels relative to other highly paid groups today are comparable to or lower than their average levels in the early 1990s although they are still above the long-term historical average. The ratio of large-company CEO pay to firm market value is similar to its levels in the late 1970s and late 1950s, and lower than its pre-1960s levels. 
On average, CEOs are paid for performance and penalized for poor performance. This has been driven by the large fraction of stock options and restricted stock in the typical CEO pay package.

Finally, boards do monitor CEOs and that monitoring appears to have increased over time. CEO tenures in the 2000s are lower than in the 1980s and 1990s. And CEO turnover is tied to poor stock performance.

Shareholders largely approved the current state of executive pay and corporate governance. In the first year of the Dodd-Frank mandated Say-On-Pay votes (in 2011), top executive pay policies at roughly $98 \%$ of S\&P 500 and Russell 3000 companies received majority shareholder support.

Murphy (2012) concludes his impressive and detailed survey of executive compensation with the conclusion executive compensation is affected by the interaction of a competitive market for talent, managerial power, and political factors. That conclusion is hard to disagree with.

There have been corporate governance failures and pay outliers where managerial power is surely exercised. And the pay levels are still very high relative to the typical household or person. Those are sources of the common perceptions.

That said, a meaningful part of CEO pay appears to have been driven by the market for talent. In recent decades, CEO pay is likely to have been affected by the same forces of technology and scale that have led to the general increase in incomes at the very top.

For researchers, this evidence still leaves a number of questions unanswered. In particular, it would be useful to quantify the relative contributions of the market for talent, managerial power, and other considerations. And there is certainly room for more work on understanding what incentives are appropriate under what circumstances, particularly in financial versus non-financial businesses.

And for corporate boards, this evidence explains why compensation and the role of boards are likely to remain challenging, if not controversial. The market for talent puts pressure on boards to reward their top people at competitive pay levels in order to both attract and retain them. At the same time, boards are affected by the accurate perception that pay is high relative to the median household and by the 
negative publicity from pay and governance outliers. Those perceptions and the current lackluster economy create political and popular pressure to reward top people less. 


\section{References}

Allen, Claudia, 2007, "Study of majority voting in director elections," working paper, Neal Gerber \& Eisenberg, Chicago, IL.

Bakija J., A. Cole and B. Heim, 2012, Jobs and Income Growth of Top Earners and the Causes of Changing Income Inequality: Eveidence from U.S. Tax Return Data, Working paper, Indiana University.

Baumol, William and William Bowen, 1965, "On the Performing Arts: The Anatomy of their Economic Problems,” The American Economic Review, 55:2, 95-102.

Bebchuk, Lucian and Jesse Fried, 2006, Pay without Performance: The Unfulfilled Promise of Executive Compensation, Harvard University Press.

Bertrand, M., and S. Mullainathan. 2001. Are CEOs Rewarded for Luck? The Ones Without Principals Are. Quarterly Journal of Economics 116(3):901-32.

Bizjak, J. M., M. L. Lemmon, and L. Naveen. 2008. Does the Use of Peer Groups Contribute to Higher Pay and Less Efficient Compensation? Journal of Financial Economics 90(2):152-68.

Brav, A., W. Jiang, F. Partnoy, and R. Thomas, forthcoming, "Hedge Fund Activism, Corporate Governance, and Firm Performance," Journal of Finance.

Conyon, M., J. Core, and W. Guay, 2011, “Are US CEOs Paid More Than UK CEOs? Inferences From Risk-Adjusted Pay,” Review of Financial Studies 24, 402-438.

Cronqvist, H. and R. Fahlenbrach, 2011, CEO Contract Design: How Do Strong Principals Do It? Working paper, Swiss Finance Institute.

Equilar, 2011, An Analysis of Voting Results and Performance at Russell 3000 Companies, http://www.equilar.com/knowledge-network/research-articles/2011/201107-voting-analytics.php.

Fernandes, N., M. Ferreira, P. Matos, and K.J. Murphy, 2011, Are US CEOs Paid More? New International Evidence. Working paper, University of Southern California.

Ferri, Fabrizio, and David Maber, 2010, "Say on Pay Votes and CEO Compensation: Evidence from the UK," working paper, Harvard Business School.

Frank, Robert, 2011, High-Beta Rich, New York: Crown Business Books.

Frydman, Carola, and Dirk Jenter, 2010, CEO Compensation, Annual Review of Financial Economics 2, 75-102.

Frydman, Carola and Raven E. Saks, 2010, Executive Compensation: A New View from a Long-Term Perspective, 1936-2005, Review of Financial Studies 23, 2099-2138.

Gabaix, Xavier and Augustin Landier, 2008, “Why Has CEO Pay Increased So Much?” Quarterly Journal of Economics, 123(1): 49-100. 
Gillan, S., J. Hartzell, and R. Parrino, 2005, Explicit vs. Implicit Contracts: Evidence from CEO Employment Agreements, working paper, University of Texas at Austin.

Hall, B., and J. Liebman. 1998, Are CEOs Really Paid Like Bureaucrats? Quarterly Journal of Economics 113, 653-91.

Hermalin, B. E. 2005. Trends in Corporate Governance. Journal of Finance 60:2351-84.

Hewitt, Gary and Carol Bowie, 2011, Evaluating Pay for Performance Alignment: ISS' Quantitative and Qualitative Approach, white paper, Institutional Shareholder Services, Inc.

Holderness, C. G., R. S. Kroszner, and D. P. Sheehan. 1999. Were the Good Old Days That Good? Changes in Managerial Stock Ownership Since the Great Depression. Journal of Finance 54(2):435-69.

Holmstrom, B. and S. Kaplan, 2001, Corporate Governance and Merger Activity in the United States: Making Sense of the 1980s and 1990s, Journal of Economic Perspectives 15, 121-144.

Jensen, Michael C, Kevin J. Murphy, and Eric G. Wruck, 2004, "Remuneration: Where We've Been, How We Got Here, What are the Problems, and How to Fix Them," working paper, Harvard Business School, NOM Working Paper 04-28.

Jenter, D, and K. Lewellen, 2010, "Performance induced CEO turnover," Working Paper, Stanford University.

Jorgenson, D., M. Ho, and K. Stiroh, 2008, “A Retrospective Look at the U.S. Productivity Growth Resurgence,” Journal of Economic Perspectives, 3-24.

Kaplan, S., 2008, “Are U.S. CEOs Overpaid?” Academy of Management Perspectives, May, 1-16.

Kaplan, S. and Bernadette Minton, 2012, "How has CEO Turnover Changed?" International Review of Finance, 12: 57-87.

Kaplan, S. and J. Rauh, 2010, "Wall Street and Main Street: What Contributes to the Rise in the Highest Incomes?" Review of Financial Studies, 23:1004-1050.

Kaplan, S. and P. Stromberg, 2009, "Leveraged Buyouts and Private Equity," Journal of Economic Perspectives, Winter, 121-146.

Larcker, D. and B. Tayan, 2011, Corporate Governance Matters: A Closer Look at Organizational Choices and Their Consequences, Pearson Prentice Hall.

Metrick, Andrew and Ayako Yasuda, 2010, “The Economics of Private Equity Funds," Review of Financial Studies 23 (6): 2303-2341.

Mishra, S., 2012, Parsing The Vote: CEO Pay Characteristics Relative to Shareholder Dissent, working paper, Institutional Shareholder Services.

Murphy, Kevin J., 2011, The Politics of Pay: A Legislative History of Executive Compensation, working paper, USC. 
Murphy, Kevin J., forthcoming, Executive Compensation: Where we are, and how we got there, in George Constantinides, Milton Harris, and René Stulz, eds.: Handbook of the Economics of Finance.

Murphy, Kevin J., and Jan Zábojník, 2008, Managerial Capital and the Market for CEOs.

Parker, Jonathan A., and Annette Vissing-Jørgensen, 2010, "The Increase in Income Cyclicality of HighIncome Households and its Relation to the Rise in Top Income Shares", Brookings Papers on Economic Activity, Fall, 1 - 70.

Peters, Florian and A. Wagner, 2012, The Executive Turnover Risk Premium, working paper, Swiss Finance Institute.

Philippon, T. and A. Reshef, 2008, "Wages and Human Capital in the U.S. Financial Industry: 1909-2006," working paper, NYU.

Piketty, Thomas and Saez, Emmanuel, 2003, "Income Inequality in the United States, 1913- 1998," Quarterly Journal of Economics 118: 1-39. Tables and Figures Updated to 2010 in Excel format, March 2012).

Piketty, Thomas and Saez, Emmanuel, 2006a, "The Evolution of Top Incomes: A Historical and International Perspective," American Economic Review 96 (2), 200-206.

Rosen, Sherwin, 1981, “The Economics of Superstars,” American Economic Review 71(5), 845-858.

Spencer Stuart, 2012, Spencer Stuart Board Index.

Taylor, Lucian A., 2010, Why are CEOs rarely fired? Evidence from structural estimation, Journal of Finance 65(6): 2051-2087.

Thomas, R., A. Palmiter, and J. Cotter, 2011, Frank-Dodd's Say on Pay: Will It Lead to a Greater Role for Shareholders in Corporate Governance? Working paper, Vanderbilt University Law School.

Van Ark, B., M. O’Mahoney, and M. Timmer, 2008, “The Productivity Gap between Europe and the United States: Trends and Causes,” Journal of Economic Perspectives, 25-44. 
Figure 1:

Average \& Median Total Pay (estimated)

of S\&P 500 CEOs from 1993 to 2010 (in millions of 2010 \$)

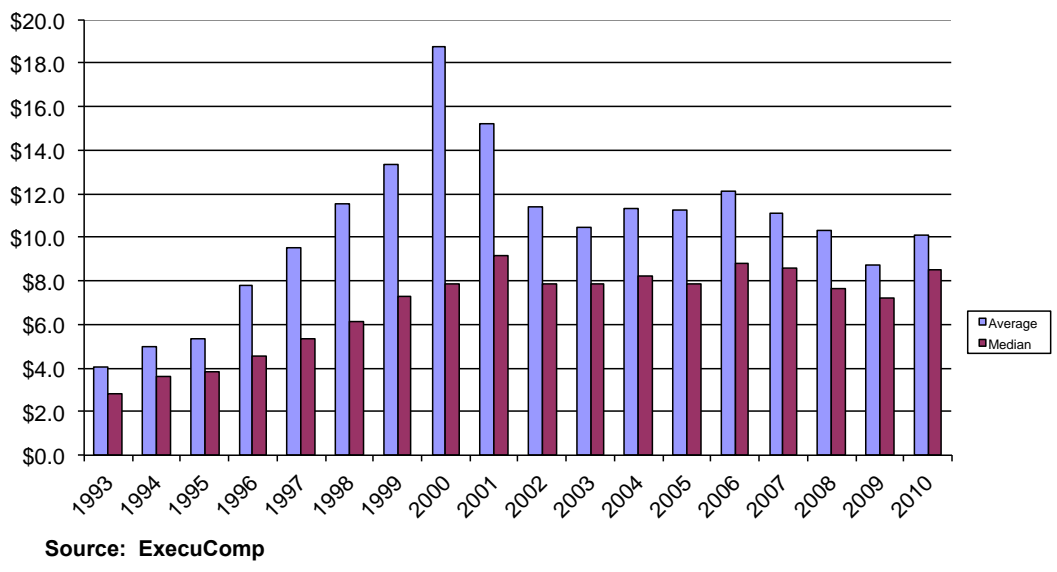

Figure 2:

Average \& Median Total Pay (estimated)

of S\&P 500 CEOs to Median Household Income

from 1993 to 2010

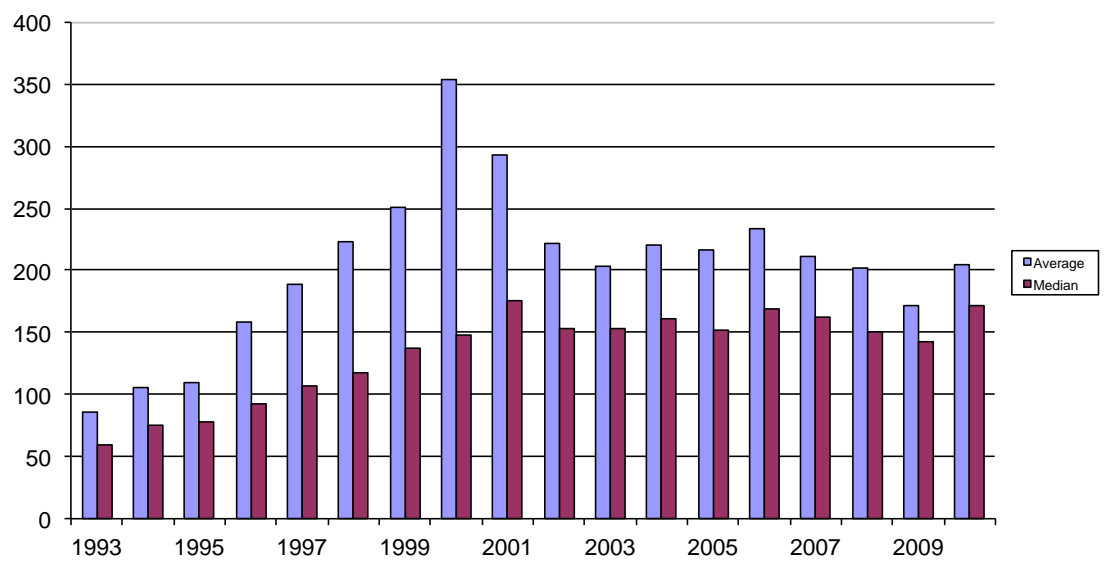

Source: ExecuComp, Census Accounts, Steven Kaplan 
Figure 3

Average \& Median Total Pay (Realized) of S\&P 500 CEOs from 1993 to 2010 (in millions of $2010 \$$ )

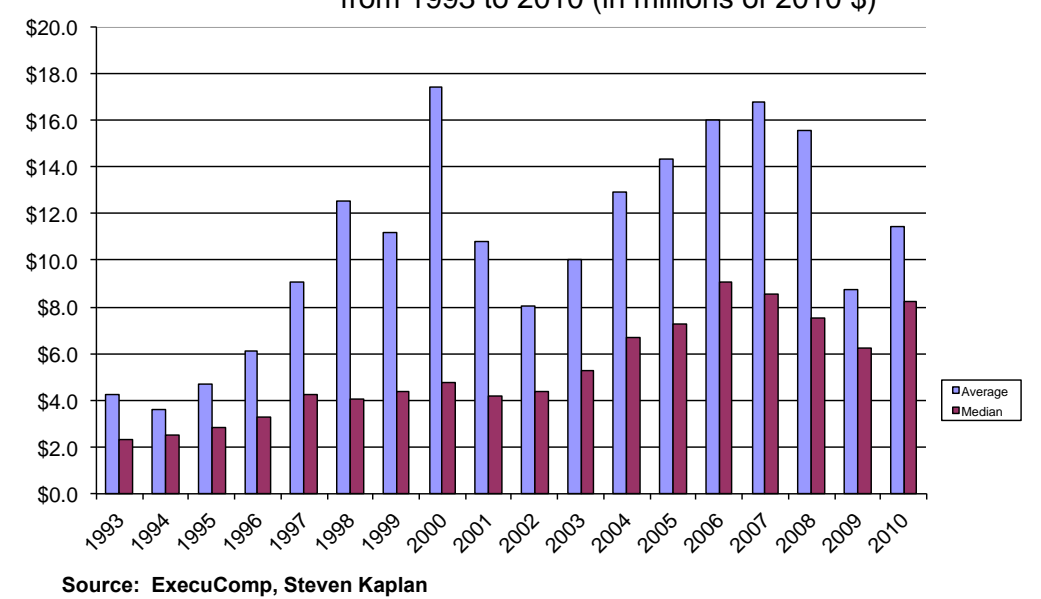

Figure 4

Average \& Median Total Pay (Realized) of S\&P 500 CEOs to Median Household Income from 1993 to 2010

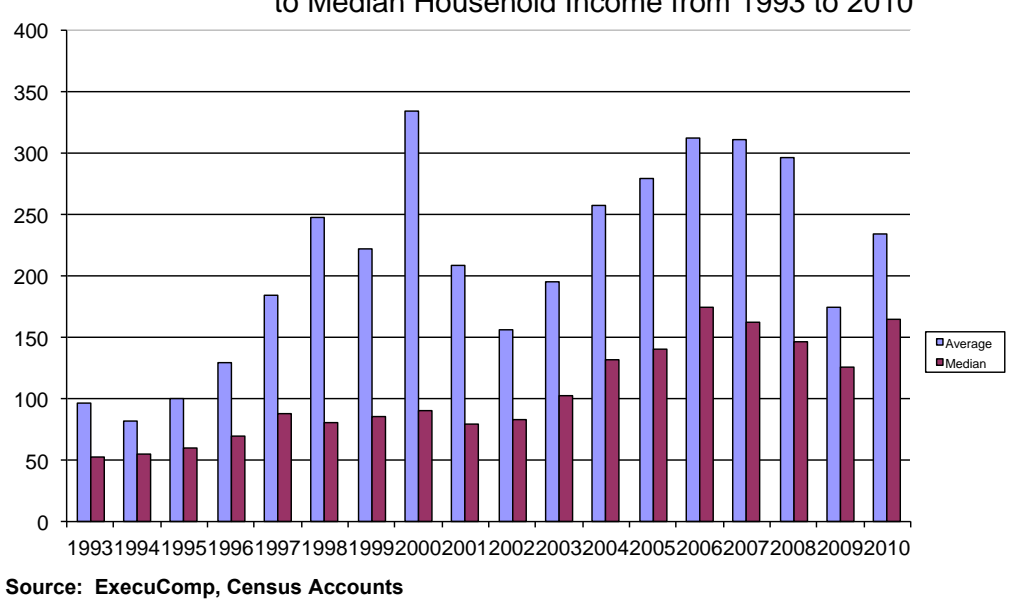


Figure 5

Average \& Median Total Pay (estimated)

of Non-S\&P 500 CEOs from 1993 to 2010 (in millions of 2010 \$)

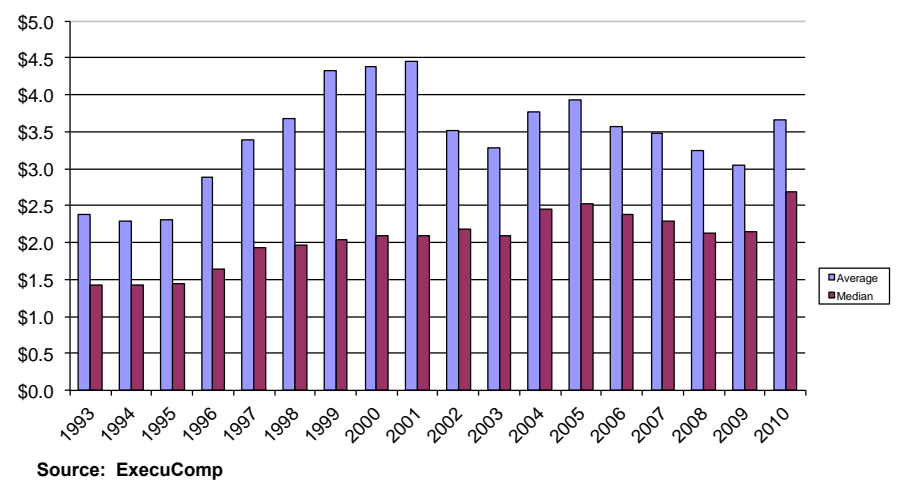

Figure 6

Average \& Median Total Pay (estimated) of non-S\&P 500

CEOs to Median Household Income from 1993 to 2010

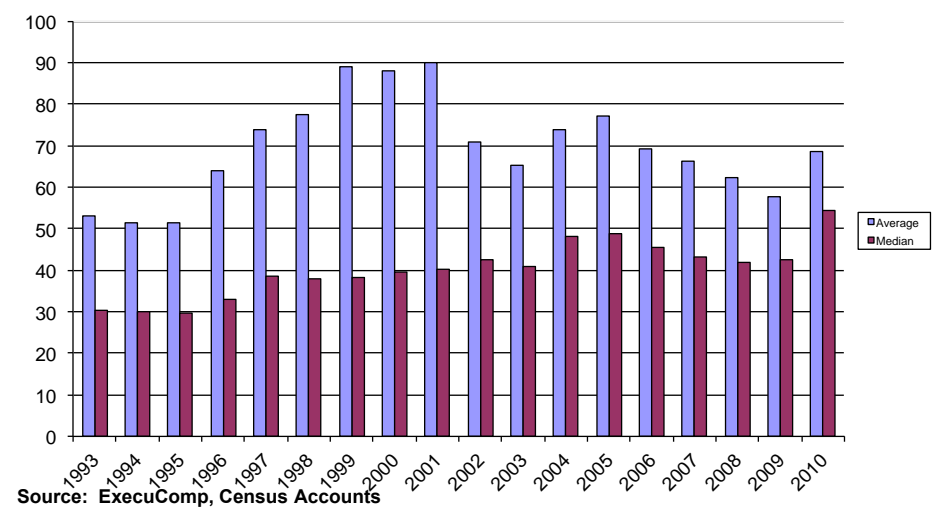

Figure 7

Average \& Median Total Pay (Realized) of

non-S\&P 500 CEOs from 1993 to 2010 (millions of 2010 \$)

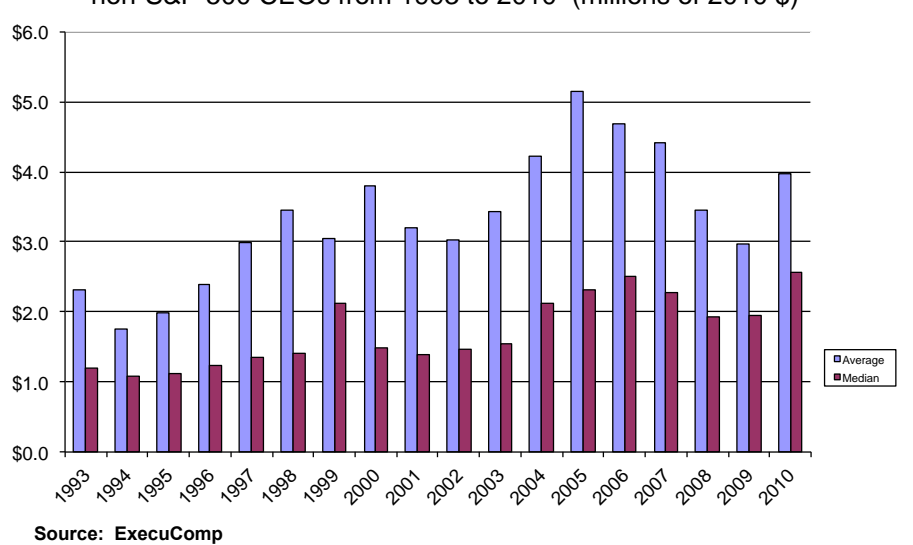


Figure 8

Income Share (AGI) of Top 0.1\% in U.S. from $1913-2010$

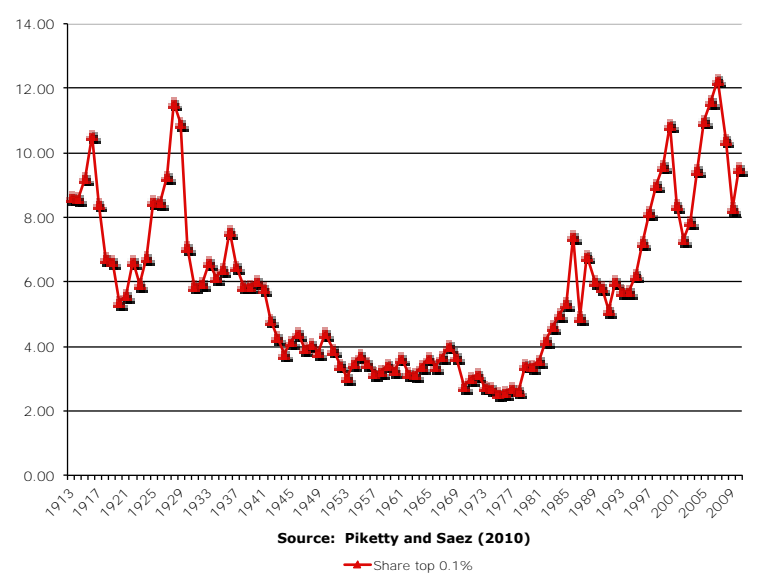

Figure 9

Income Share (AGI) of Top 0.1\% in U.S. from $1989-2010$

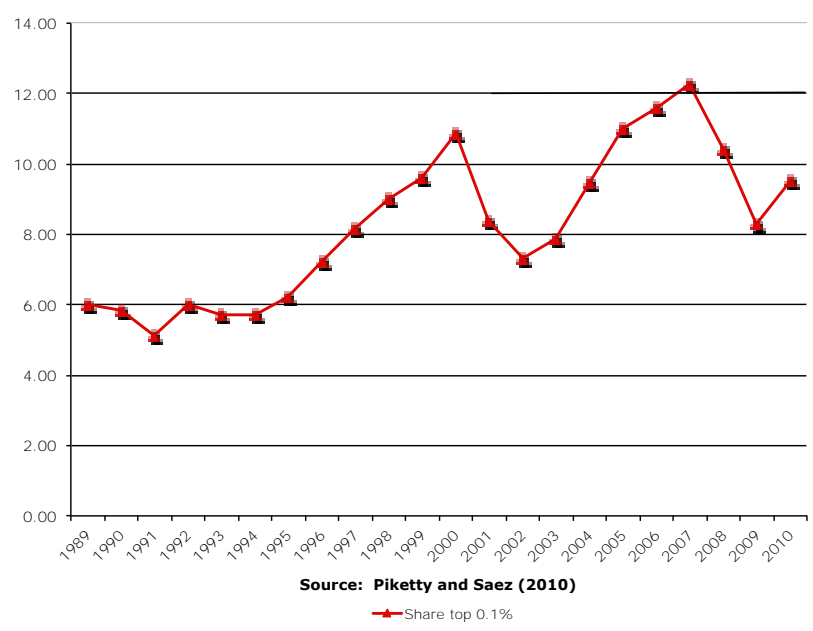

Figure 10

Average Pay (Estimated) of S\&P 500 CEOs to

Average AGI of Top $0.1 \%$ of Taxpayers from 1993 to 2010

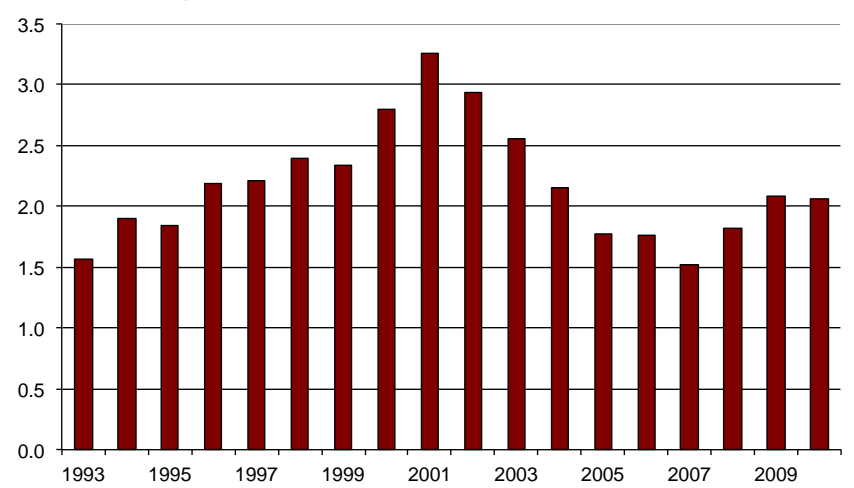

Source: ExecuComp, Piketty and Saez (2010) 
Figure 11

Average Pay (Ex Ante) of non-SP 500 ExecuComp CEOs to Average AGI of Top $0.1 \%$ of Taxpayers from 1993 to 2010

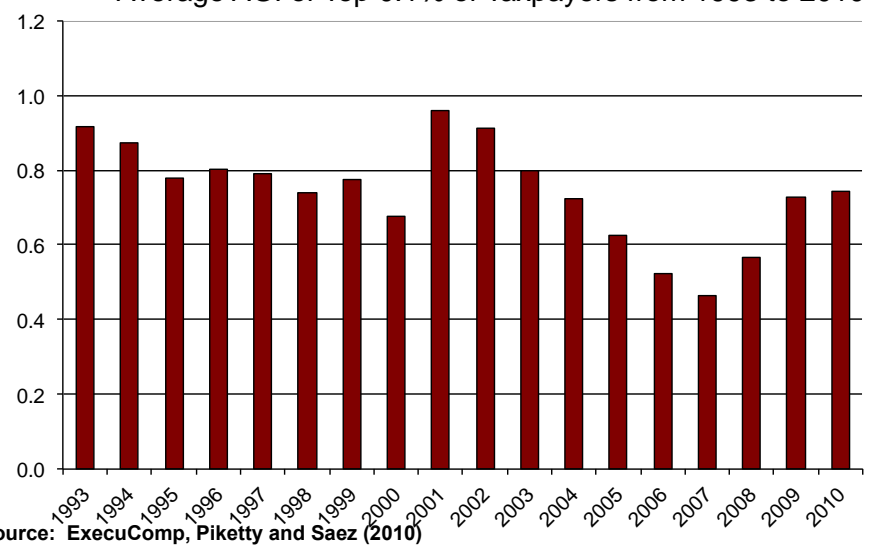

Figure 12

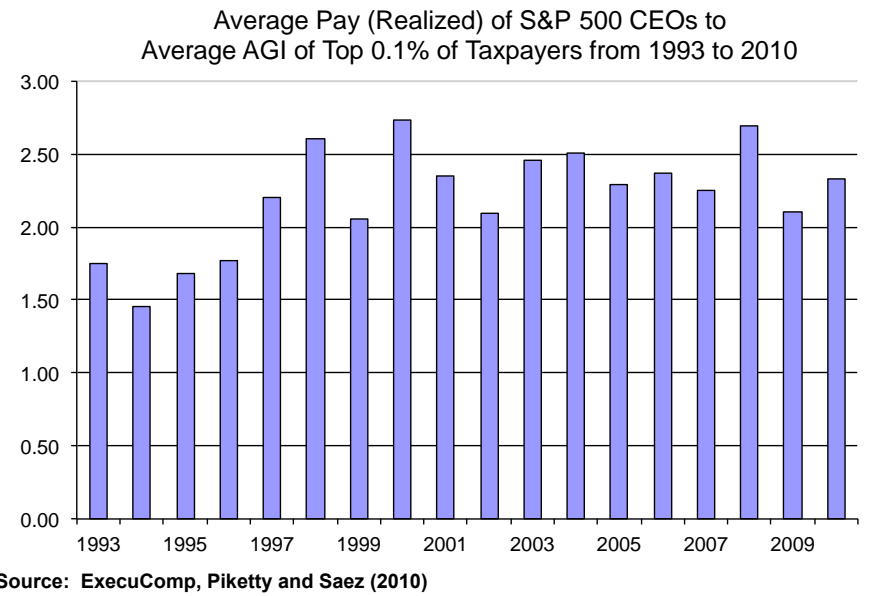

Figure 13

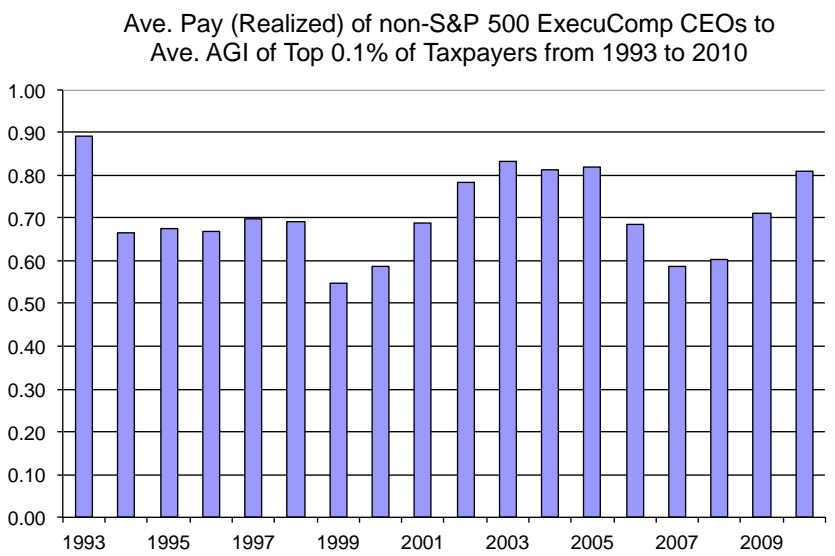

Source: ExecuComp, Piketty and Saez (2010) 
Figure 14

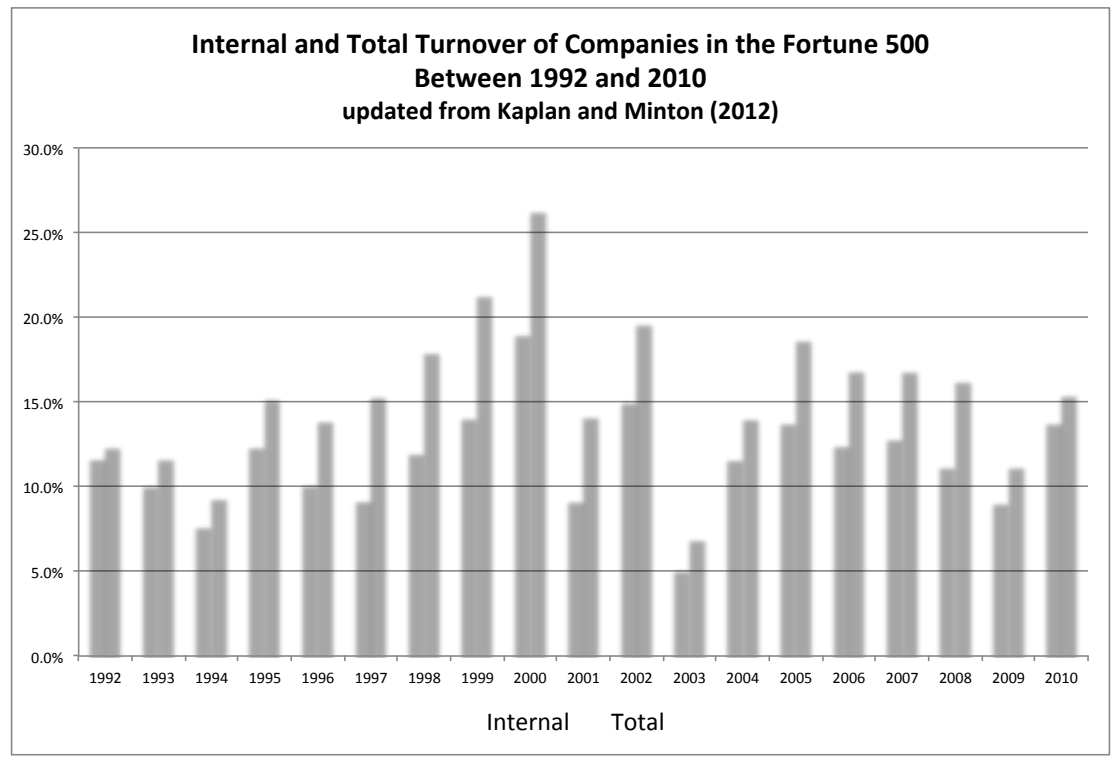

Figure 15

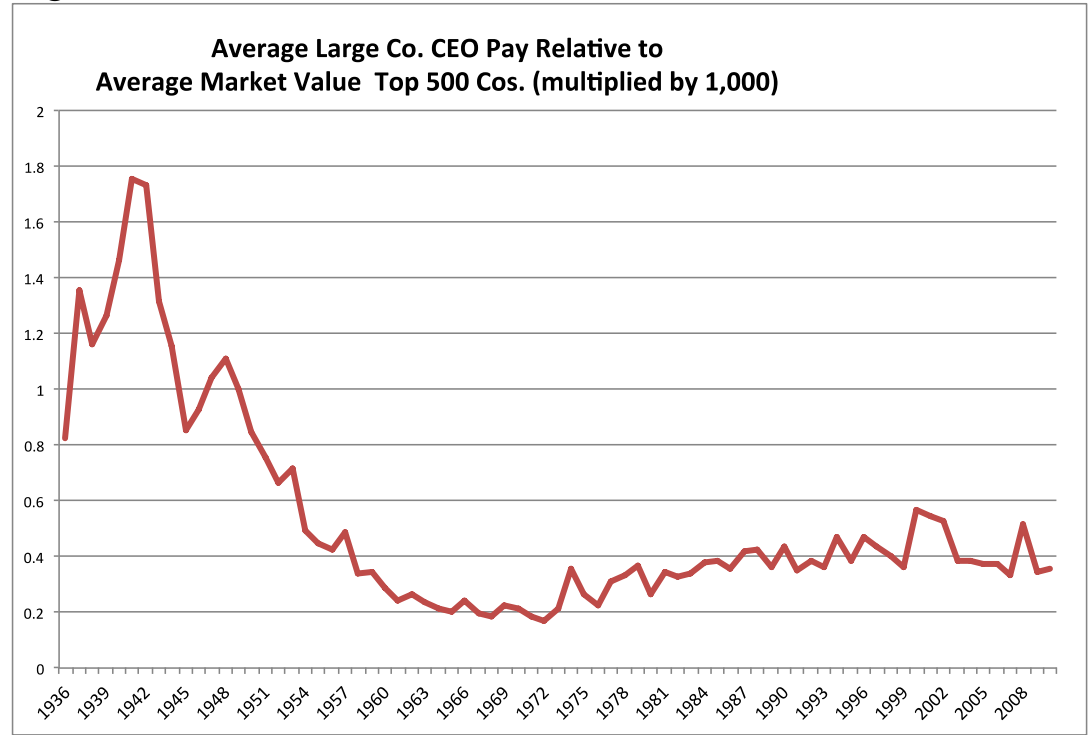

Source: S\&P 500 CEO Pay 1992 to 2010 from ExecuComp, Large Company CEO Pay 1980 to 1992 from Hall and Leibman (1998), and Large Company CEO Pay from 1936 to 1980 Frydman and Saks (2010). Average market value of top 500 companies from CRSP from 1936 to 2010. 
Figure 16

Ave. Large Co. CEO Pay Relative to Ave. Market Value Top 500 Cos. (multiplied by 1,000) from 1955 - 2010

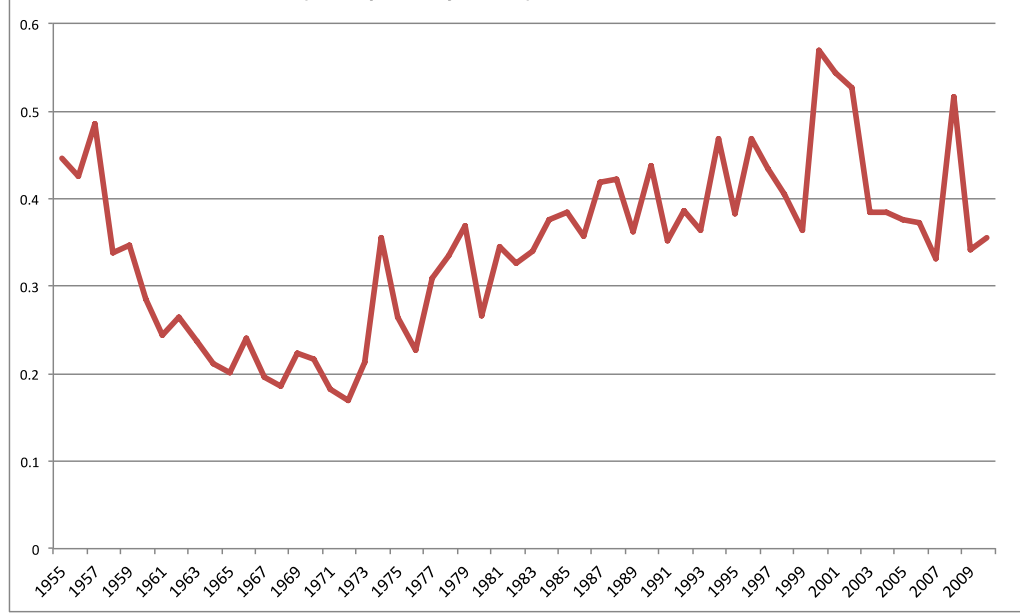

Source: S\&P 500 CEO Pay 1992 to 2010 from ExecuComp, Large Company CEO Pay 1980 to 1992 from Hall and Leibman (1998), and Large Company CEO Pay from 1936 to 1980 Frydman and Saks (2010). Average market value of top 500 companies from CRSP from 1936 to 2010.

Figure 17

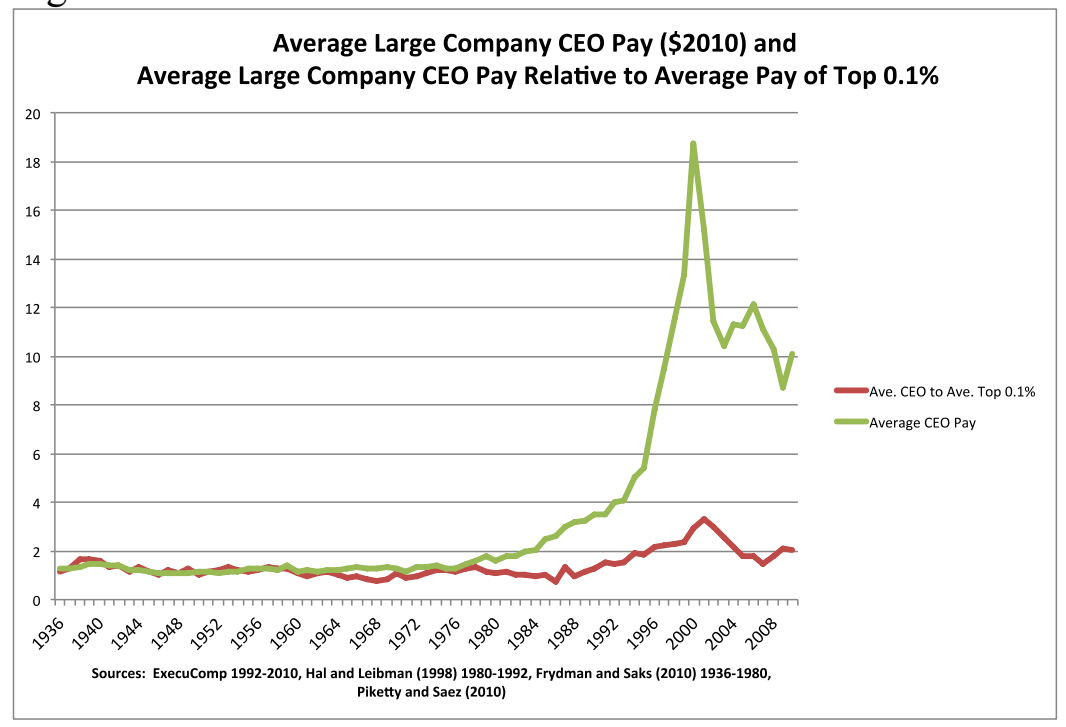

40 


\section{Figure 18}

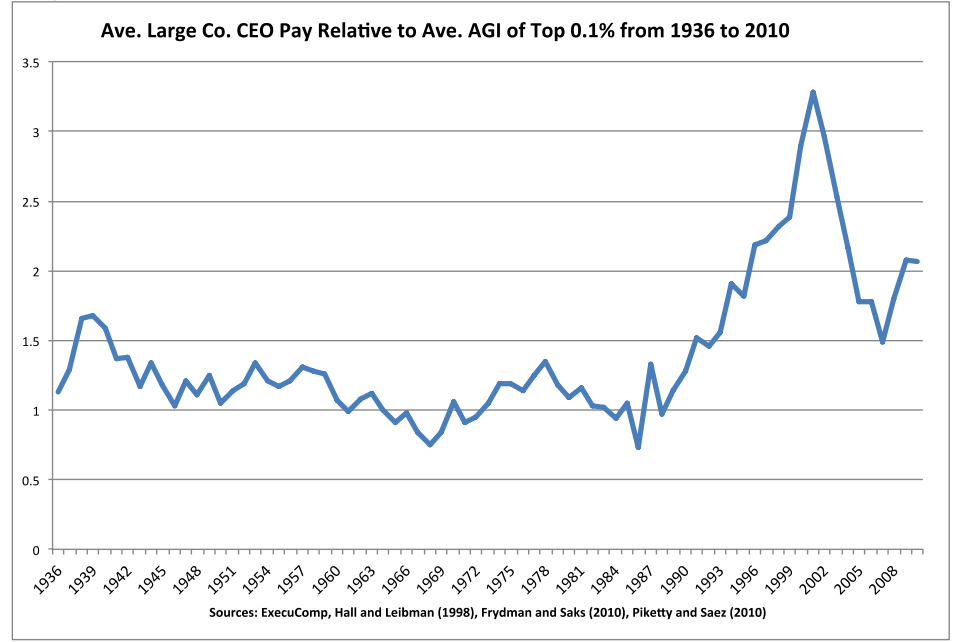

\section{Figure 19}

$\%$ of total income from individuals in top $0.1 \%$

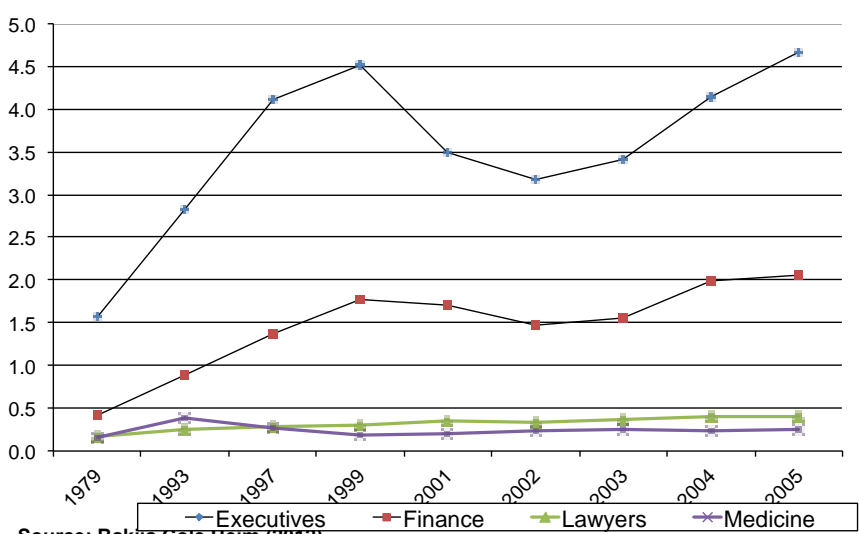
Source: Bakija Cole Heim (2012)

\section{Figure 20}

$\%$ of Total Income from Executives, Mgrs., and Supervisors in top $0.1 \%$ by Salaried or Closely-held

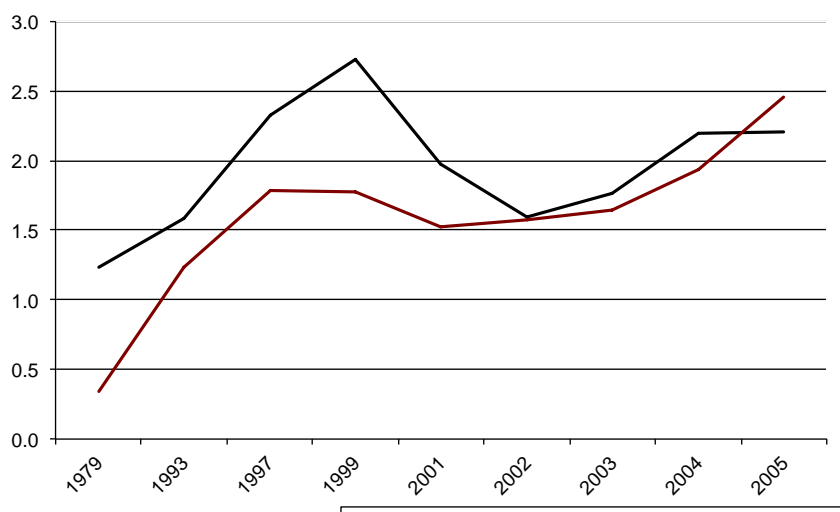

Source: Bakija Cole Heim (2012) - - Salaried (Public?) -Closely-Held (Private?) 
Figure 21

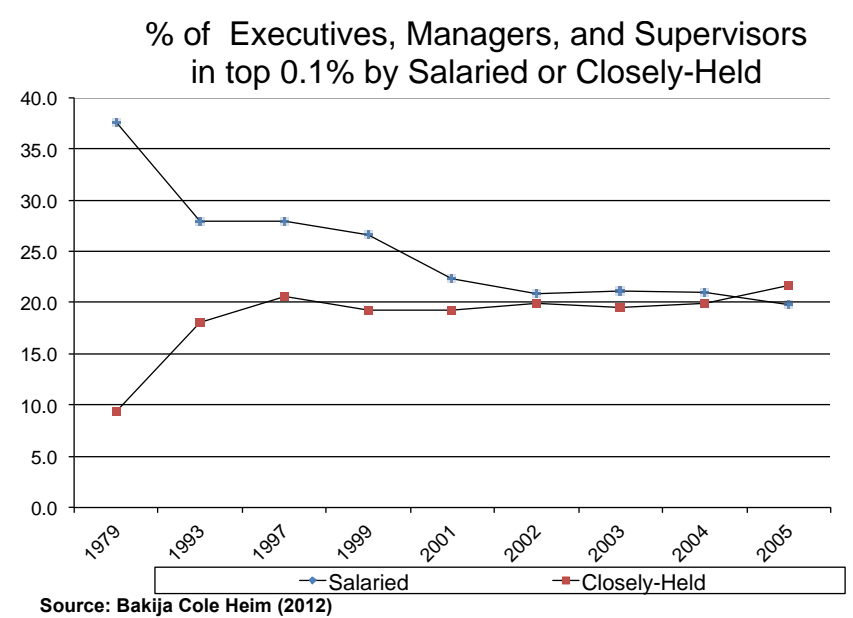

Figure 22

Average Profit Per Partner at Top 50 Law Firms from 1994 to 2010 (in millions of $2010 \$$ )

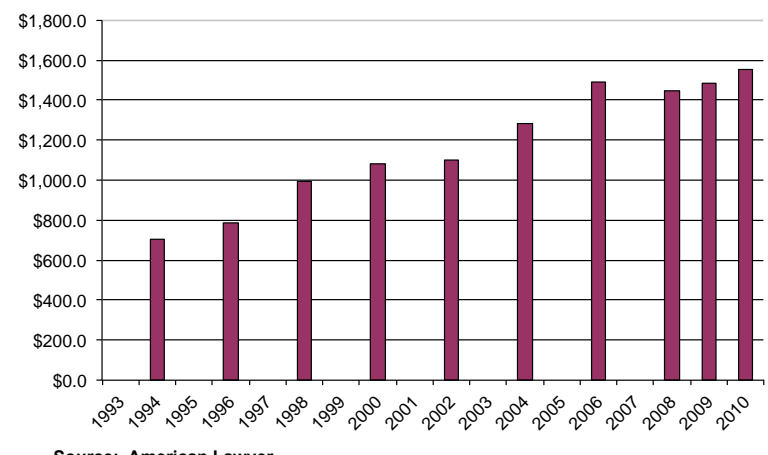

Source: American Lawyer

Figure 23

Average Profit Per Partner at Top 50 Law Firms to

Pay of Median Household Income from 1994 to 2010

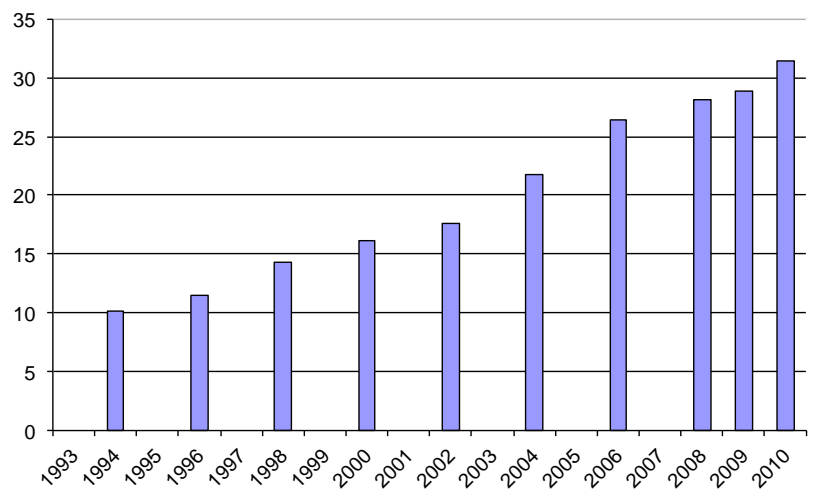

Source: American Lawyer, Census 
Figure 24

Average Profit Per Partner at Top 50 Law Firms to

Average AGI of Top $0.1 \%$ from 1994 to 2010

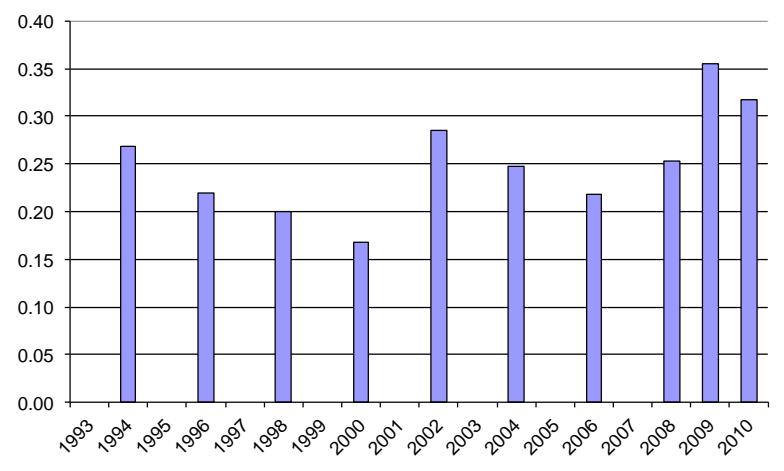

Source: American Lawyer, Piketty and Saez (2010)

Figure 25

S\&P 500 CEO Estimated Pay to Average Profit Per Partner at Top 50 Law Firms from 1994 to 2010

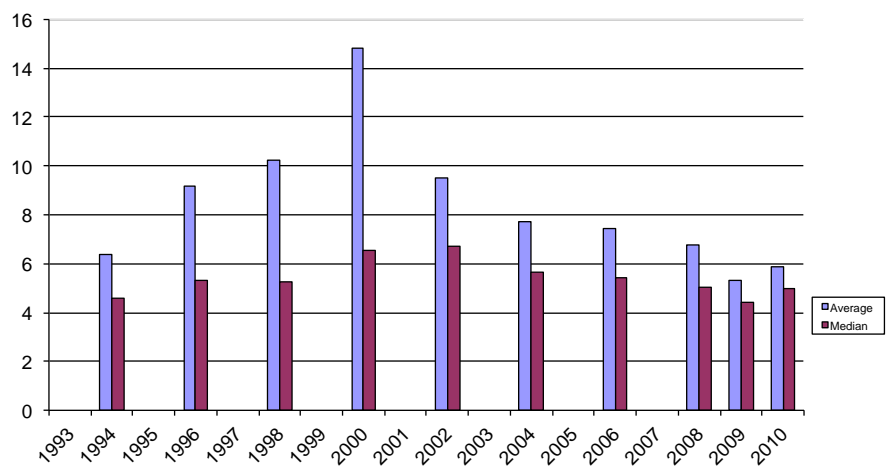

Source: ExecuComp, American Lawyer

Figure 26

Non-S\&P 500 CEO Estimated Pay to Average Profit Per Partner at Top 50 Law Firms from 1994 to 2010

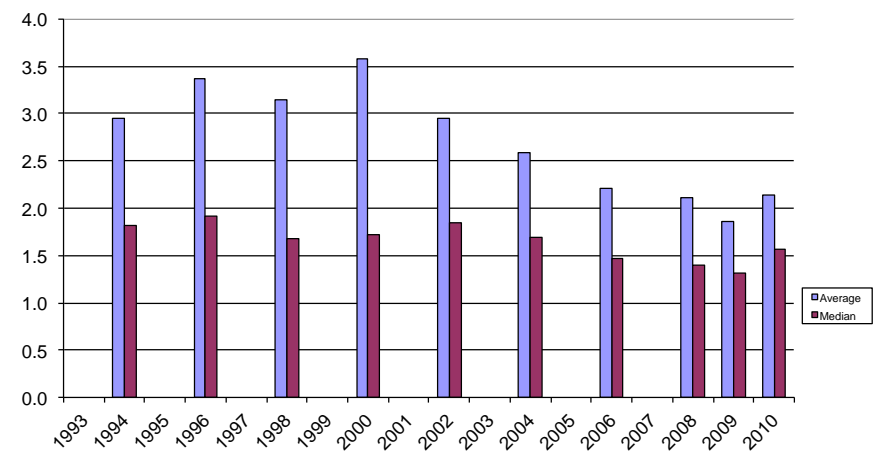

Source: ExecuComp, American Lawyer 
Figure 27

Average Pay of Top 25 Hedge Fund Managers

AR Magazine "Rich List" from 2001 to 2011 (in millions of \$2010)

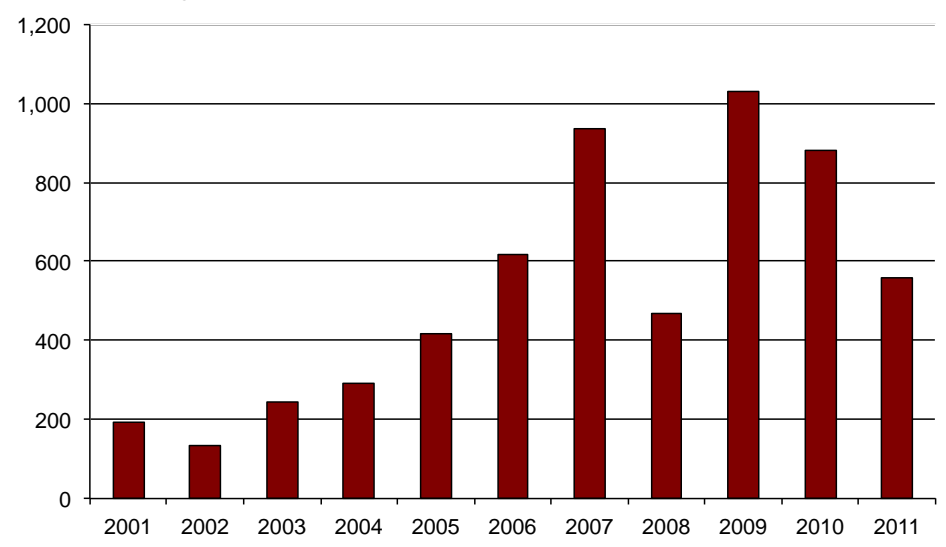

Source: AR Magazine Rich Lists

Figure 28

Total Pay of 25 Top 25 Hedge Fund Managers to

Total Estimated Pay of 500 S\&P 500 CEOs from 2001 to 2010

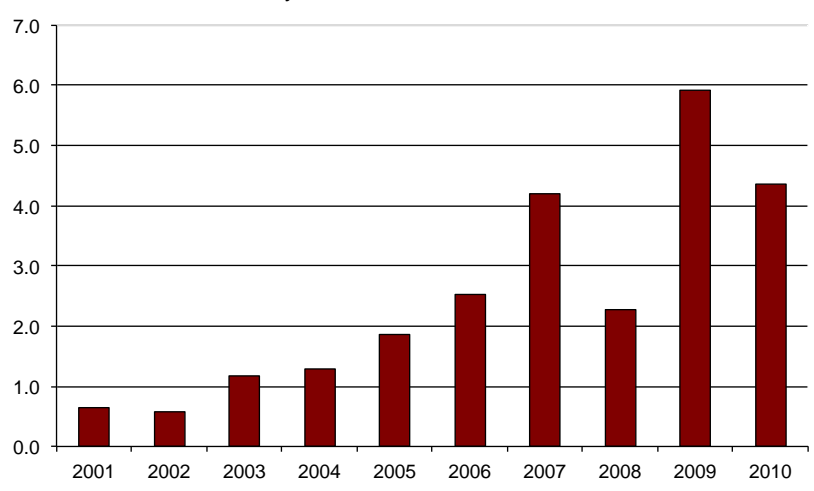

Source: ExecuComp, AR Magazine Rich Lists 
Figure 29

Estimated Fees U.S. PE and VC Funds

Using Annual Returns (in billions of 2010 \$)

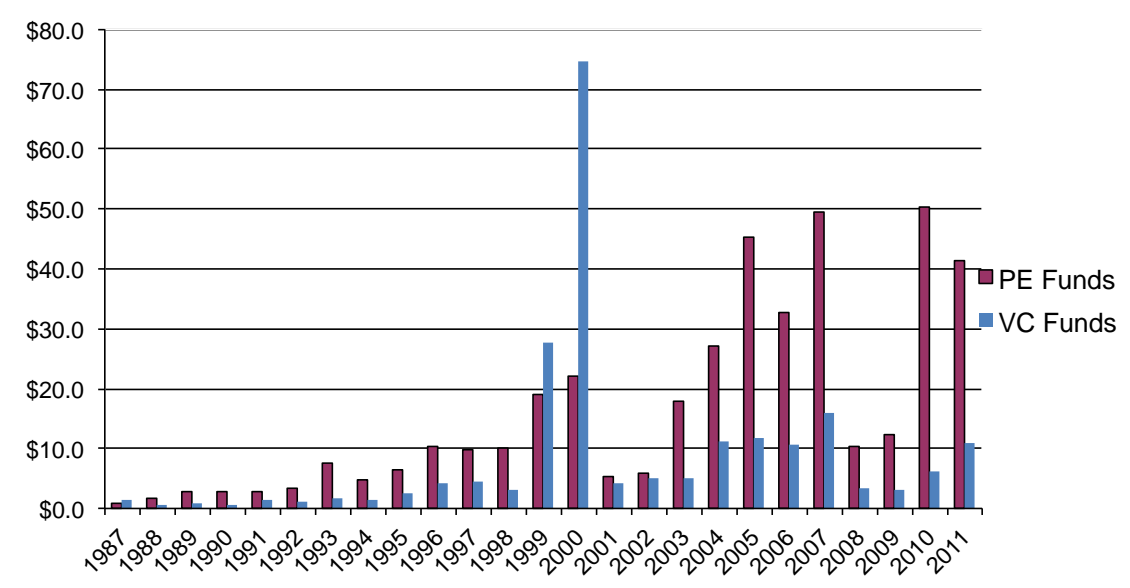

Source: Private Equit Analyst, Cambridge Asociates, Steven Kaplan

Figure 30

Estimated Fees U.S. PE and VC Funds

Assuming $4 \%$ and $5 \%$ of AUM (in billions of $2010 \$$ )

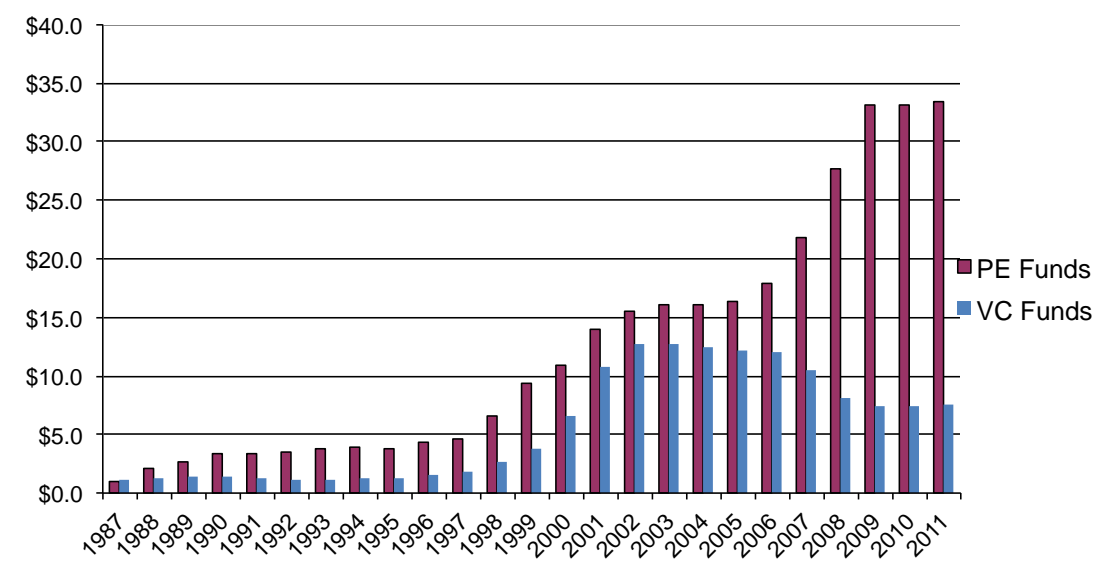

Source: Private Equit Analyst, Cambridge Asociates, Steven Kaplan 
Figure 31

Average Top 25 Salaries in Professional

Baseball, Basketball and Football (in millions of 2010 \$)

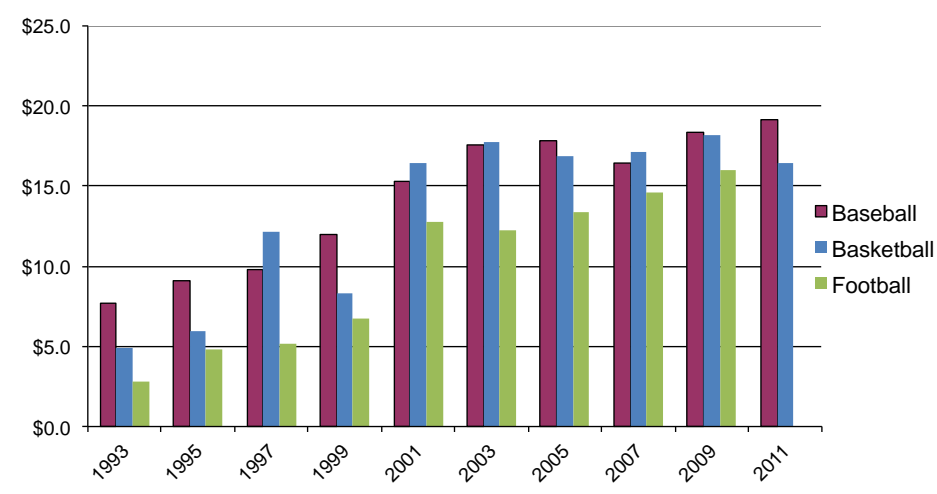

Figure 32

S\&P 500 CEO Estimated Pay to Average Pay of Top 25 Baseball, Basketball and Football Players

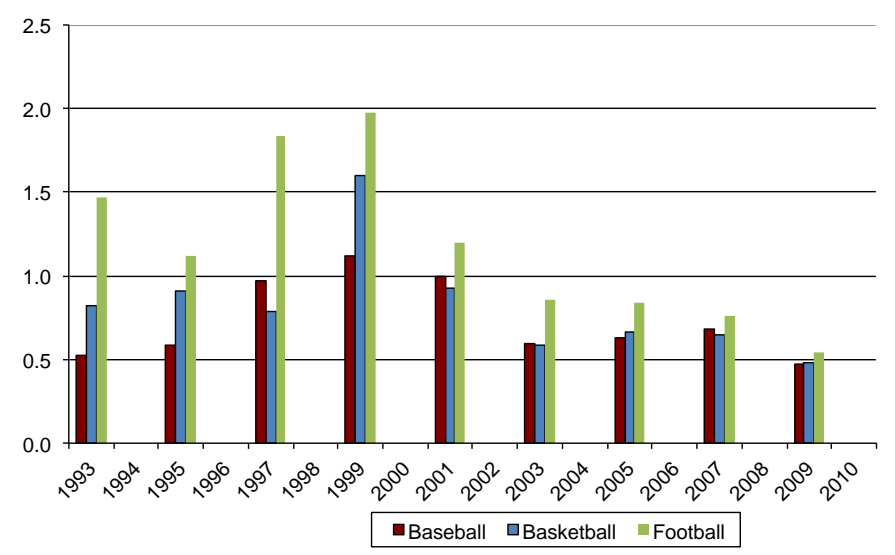

Figure 33

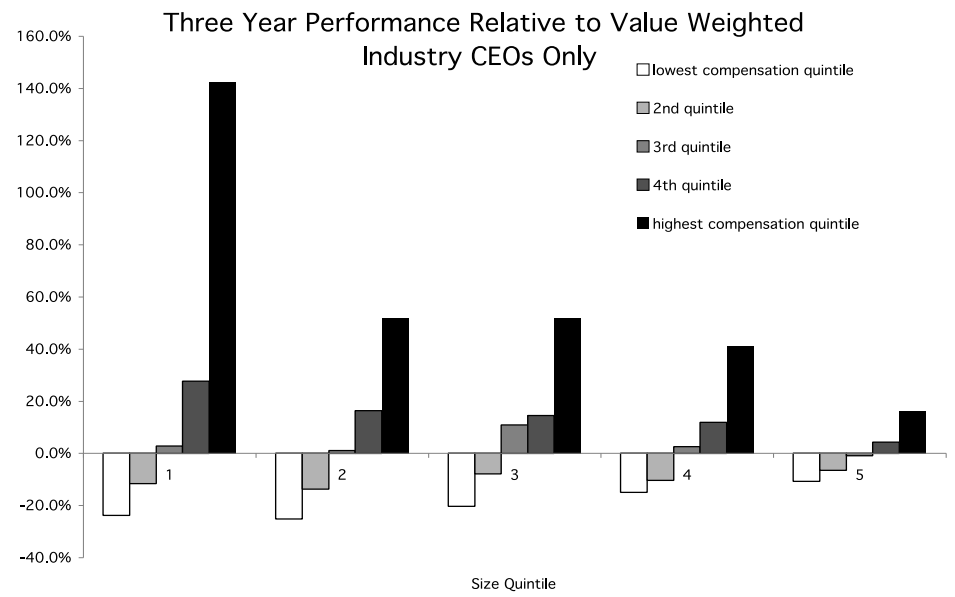

Source: Kaplan and Rauh (2008) 
Figure 34

Average Realized Pay of S\&P 500 CEOs vs. S\&P 500 from 1993 to 2010 (in millions of 2010 \$)

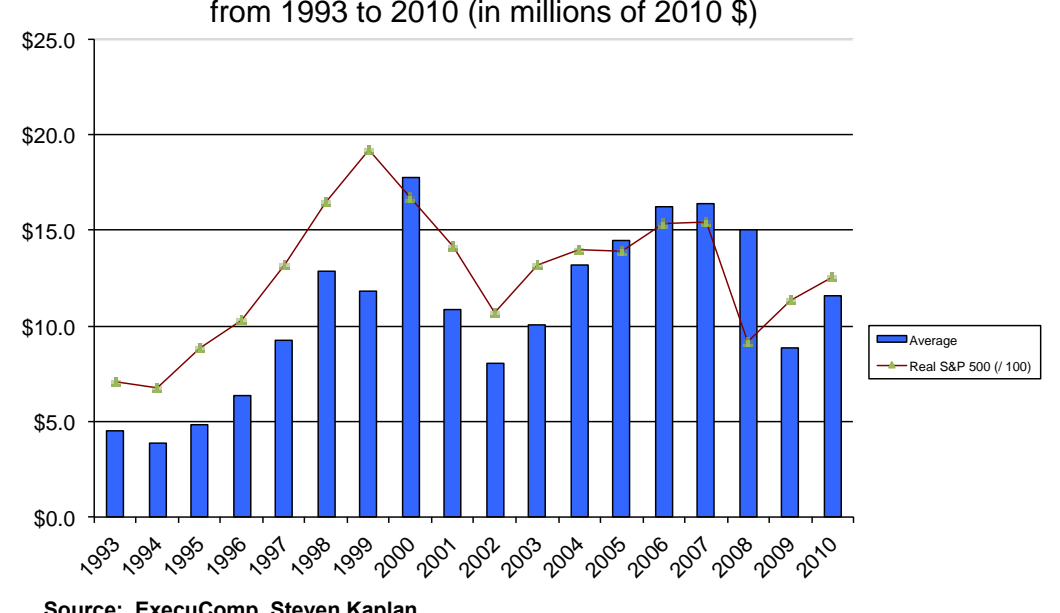

Source: ExecuComp, Steven Kaplan

Figure 35

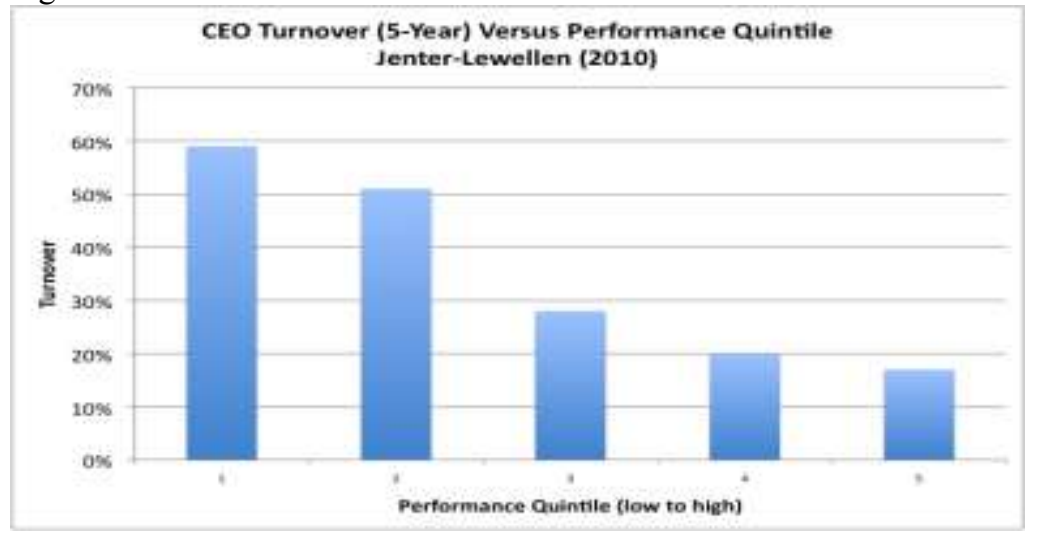

Figure 36

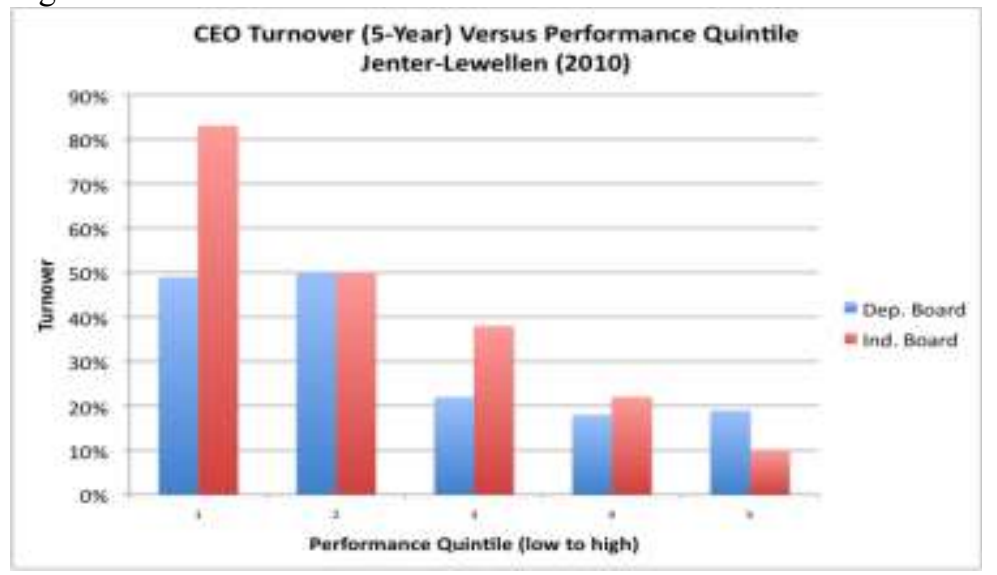


Figure 37

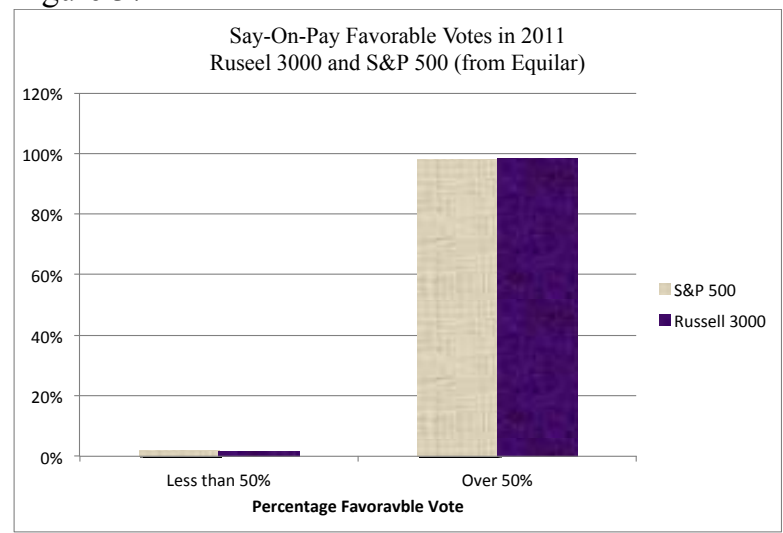

Figure 38

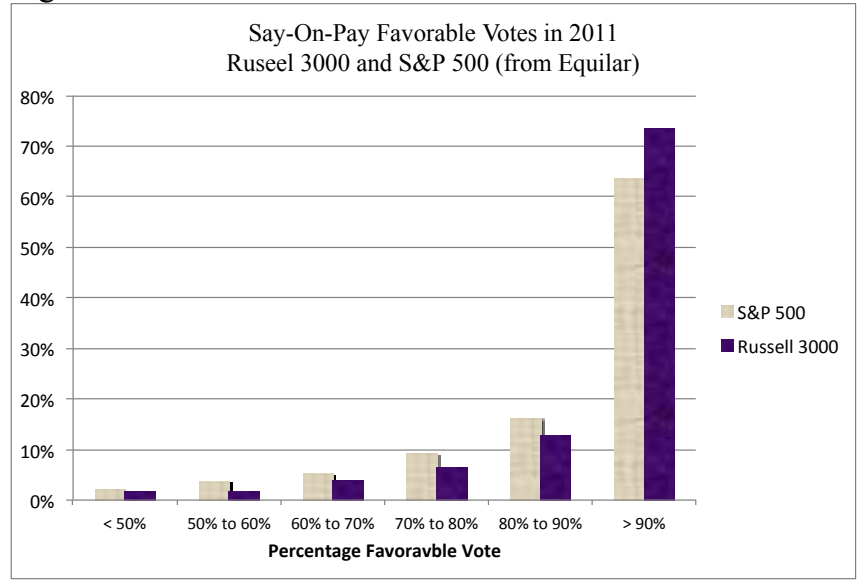

Figure 39

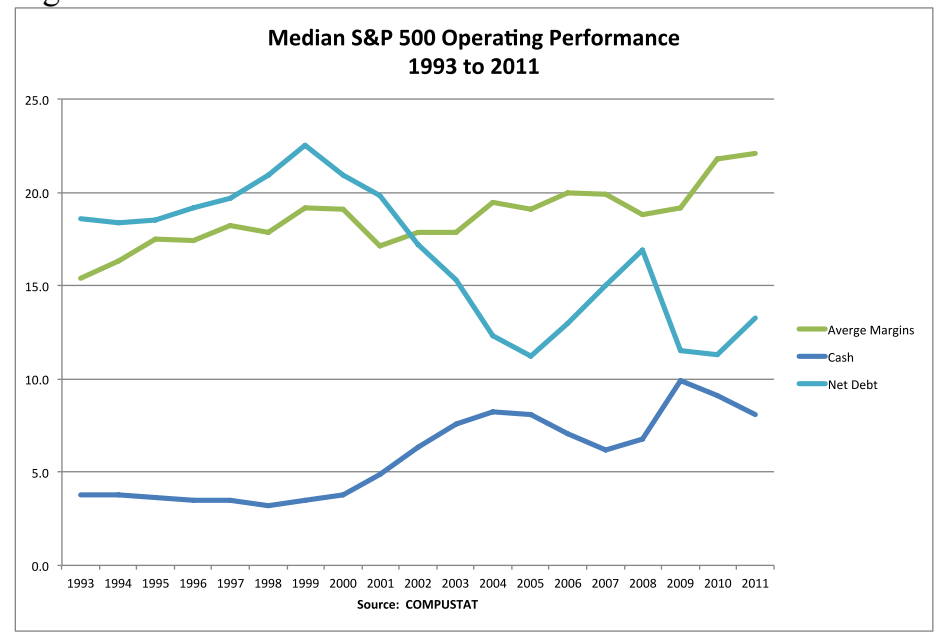


Figure 40

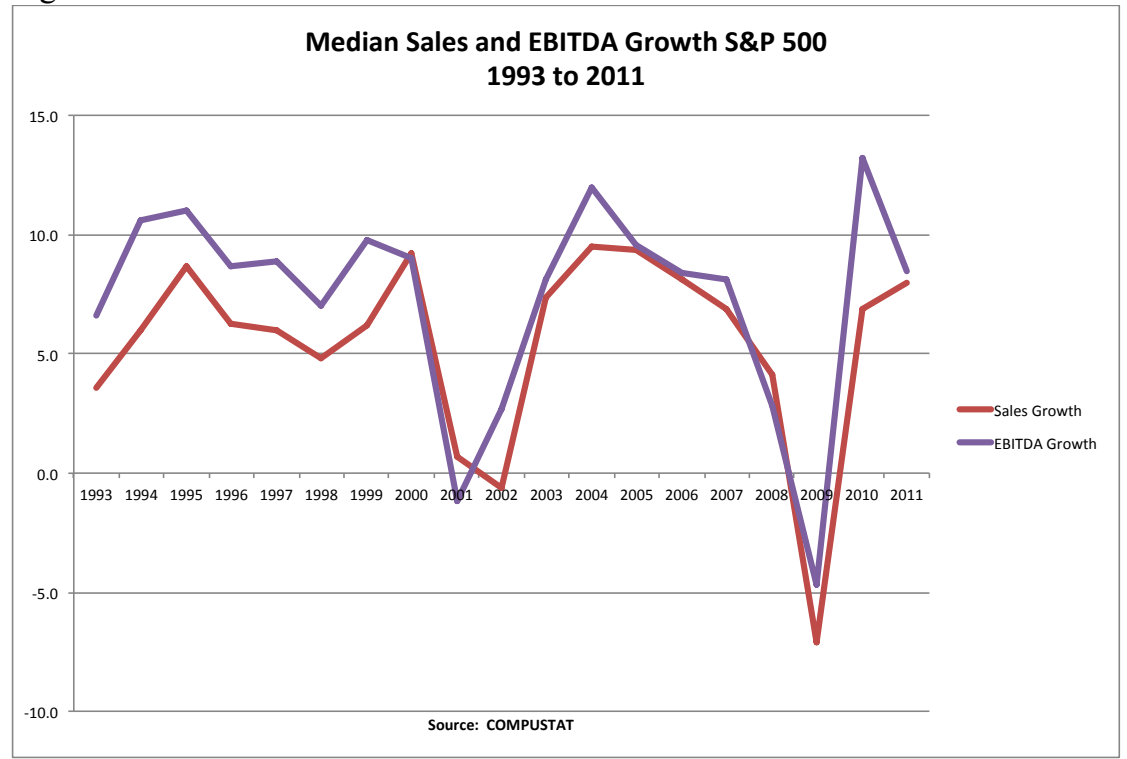

